\title{
Functional Properties of Perigeniculate Inhibition of Dorsal Lateral Geniculate Nucleus Thalamocortical Neurons In Vitro
}

\author{
Maria V. Sanchez-Vives and David A. McCormick \\ Section of Neurobiology, Yale University School of Medicine, New Haven, Connecticut 06510
}

The properties of the inhibitory influence of neurons in the perigeniculate (PGN) nucleus on thalamocortical cells were examined with intracellular recordings in the ferret geniculate slice maintained in vitro. Activation of PGN neurons with the local application of glutamate caused IPSPs in thalamocortical neurons that were mediated by both $\mathrm{GABA}_{A}$ and $\mathrm{GABA}_{\mathrm{B}}$ receptors, as well as the activation of spindle waves.

With low intensity stimulation of the PGN, local application of bicuculline to the dorsal lateral geniculate nucleus (LGNd) strongly inhibited evoked and spindle-associated IPSPs, indicating that these are largely mediated by $\mathrm{GABA}_{\mathrm{A}}$ receptors. The generation of $\mathrm{GABA}_{\mathrm{B}}$ receptor-mediated IPSPs in thalamocortical cells that were large enough to generate rebound low threshold $\mathrm{Ca}^{2+}$ spikes required substantially increased activation of the PGN with glutamate.
The activation of synchronous bicuculline-induced slowed oscillations in thalamocortical neurons required the block of $\mathrm{GABA}_{\mathrm{A}}$ receptors in the $L G N d$ as well as in the PGN. These results indicate that bursts of action potentials in $P G N$ neurons can result in the activation of both $\mathrm{GABA}_{A}$ and $\mathrm{GABA}_{B}$ receptors in thalamocortical neurons, with the strong activation of $\mathrm{GABA}_{\mathrm{B}}$ receptors requiring an intense, simultaneous discharge of a number of PGN neurons. Functionally, these results suggest that PGN neurons inhibit thalamocortical cells preferentially through the activation of $\mathrm{GABA}_{\mathrm{A}}$ receptors, although the strong activation of $\mathrm{GABA}_{\mathrm{B}}$ receptors may occur under pathological conditions and contribute to the generation of abnormal, synchronous slow oscillations.

Key words: inhibition; thalamus; sleep; thalamic reticular nucleus; GABAergic; oscillations
The thalamic reticular nucleus is a collection of GABAergic neurons situated in the bundles of corticothalamic and thalamocortical fibers that course between the thalamus and cerebral cortex. These neurons are innervated by axon collaterals from thalamocortical cells as well as from corticothalamic fibers and give rise to a dense innervation of particular regions of thalamic nuclei (for review, see Steriade and Deschênes, 1984; Jones, 1985; McCormick, 1992). The perigeniculate nucleus (PGN) appears to be equivalent to the thalamic reticular nucleus and is intimately interconnected with the dorsal lateral geniculate nucleus (LGNd).

The functional role of the thalamic reticular and perigeniculate nuclei has been most extensively studied as it relates to sleep and the generation of spindle waves. Spindle waves are 1-3 sec periods of synchronized $6-14 \mathrm{~Hz}$ oscillations and are generated largely through a reciprocal interaction between the GABAergic neurons of the thalamic reticular/perigeniculate nuclei and thalamocortical neurons (Steriade et al., 1985, 1993; Buzsáki et al., 1990; von Krosigk et al., 1993; Bal et al., 1995a,b). During the generation of spindle waves, burst firing in thalamic reticular/perigeniculate neurons results in IPSPs that are mediated mostly through the activation of $\mathrm{GABA}_{\mathrm{A}}$ receptors in thalamocortical cells. These IPSPs result in the generation of rebound low threshold $\mathrm{Ca}^{2+}$ spikes which then excite again the thalamic reticular/perigenicu-

Received June 17, 1997; revised Aug. 4, 1997; accepted Aug. 28, 1997.

This research was supported by grants from National Institutes of Health, the Klingenstein Fund, and the Human Frontier Science Program. M.V.S.-V. was a fellow of NATO and the Epilepsy Foundation of America. We thank Uhnoh Kim, Thierry Bal, and Alain Destexhe for helpful discussions.

Additional information concerning this and related research may be obtained at http://info.med.yale.edu/neurobio/mccormick/mccormick.html.

Correspondence should be addressed to David A. McCormick, Section of Neurobiology, Yale University School of Medicine, 333 Cedar Street, New Haven, Connecticut 06510.

Copyright (C) 1997 Society for Neuroscience $\quad 0270-6474 / 97 / 178880-14 \$ 05.00 / 0$ late neurons. Although the activation of $\mathrm{GABA}_{\mathrm{B}}$ receptors is particularly effective in generating rebound burst discharges in thalamocortical cells (Crunelli and Leresche, 1991), a functional role for the activation of these receptors in the generation of spindle waves has not been demonstrated.

Interestingly, rodent models of absence seizures suggest that the activation of $\mathrm{GABA}_{\mathrm{B}}$ receptors in the thalamus is particularly important in the generation of spike-and-wave epileptic activity (Hosford et al., 1992; Snead, 1992). Antagonism of GABA receptors throughout the ferret geniculate slice results in a transformation of spindle waves into a synchronized $2-4 \mathrm{~Hz}$ slowed oscillation in which thalamocortical and perigeniculate neurons generate synchronized high frequency burst discharges (von Krosigk et al., 1993; Bal et al., 1995a,b), similar to that which occurs in at least some animal models of absence seizures (Avoli et al., 1983; 1990; Buzsáki et al., 1990; Gloor et al., 1990). We have proposed previously that this transition from normal spindle waves to the occurrence of slowed oscillations may be caused by the generation of pronounced burst firing in perigeniculate neurons resulting in part from disinhibition from neighboring PGN cells (Bal et al., 1995a,b).

Previous studies in rodent thalamic slices have demonstrated that electrical stimulation in the region of the thalamic reticular nucleus can activate $\mathrm{GABA}_{\mathrm{A}}$ receptors (Thomson, 1988; Warren et al., 1994; Ulrich and Huguenard, 1995) or both GABA $_{\mathrm{A}}$ and $\mathrm{GABA}_{\mathrm{B}}$ receptor-mediated IPSPs in thalamocortical neurons (Huguenard and Prince, 1994). However, the studies by Bal et al. $(1995 a, b)$ suggest that $\mathrm{GABA}_{\mathrm{B}}$ receptors are only weakly activated during the generation of spindle waves, but were strongly activated during the occurrence of bicuculline-induced slowed oscillations, when PGN neurons generate prolonged burst discharges. These findings suggest that there may be a functionally 
important difference in the properties of activation of $\mathrm{GABA}_{\mathrm{A}}$ and $\mathrm{GABA}_{\mathrm{B}}$ receptor-mediated IPSPs in thalamocortical neurons.

In this and the accompanying paper (Sanchez-Vives et al., 1997) we demonstrate that PGN neurons can activate $\mathrm{GABA}_{\mathrm{A}}$ and $\mathrm{GABA}_{\mathrm{B}}$ receptor-mediated IPSPs in thalamocortical as well as PGN neurons and that the block of $\mathrm{GABA}_{\mathrm{A}}$ receptors in both the PGN and LGNd is required for the generation of the bicuculline-induced slowed oscillation.

Some of these findings have been published previously in abstract form (Sanchez-Vives et al., 1995).

\section{MATERIALS AND METHODS}

For the preparation of slices, male or female ferrets, $\sim 2-3$ months old, were deeply anesthetized with sodium pentobarbital $(30 \mathrm{mg} / \mathrm{kg})$ and decapitated. The forebrain was rapidly removed, and the hemispheres were separated with a midline incision. Sagittal slices (400 $\mu \mathrm{m}$ thick) were formed on a DSK microslicer (model DTK-1000; Ted Pella, Inc.). A modification (as described here) of the technique developed by Aghajanian and Rasmussen (1989) was used to increase tissue viability. During preparation of slices, the tissue was placed in a solution in which $\mathrm{NaCl}$ was replaced with sucrose while an osmolarity of $307 \mathrm{mOsm}$ was maintained. After preparation, slices were placed in an interface-style recording chamber (Fine Sciences Tools) and allowed at least $2 \mathrm{hr}$ to recover. The bathing medium contained (in $\mathrm{mm}$ ): $\mathrm{NaCl} 124, \mathrm{KCl} 2.5, \mathrm{MgSO}_{4} 1.2$, $\mathrm{NaH}_{2} \mathrm{PO}_{4} 1.25, \mathrm{CaCl}_{2} 2, \mathrm{NaHCO}_{3} 26$, dextrose 10 , and was aerated with $95 \% \mathrm{O}_{2}, 5 \% \mathrm{CO}_{2}$ to a final $\mathrm{pH}$ of 7.4 . For the first $15 \mathrm{~min}$ that the geniculate slices were in the recording chamber, the bathing medium contained an equal mixture of the normal $\mathrm{NaCl}$ and the sucrosesubstituted solutions. Bath temperature was maintained at $34-35^{\circ} \mathrm{C}$.

Intracellular recording electrodes were formed on a Sutter Instruments P-80 micropipette puller from medium-walled glass (1BF100; WPI) and beveled on a Sutter Instruments beveler. Micropipettes were filled with $1.5-2.0 \mathrm{M}$ potassium acetate and $2 \%$ biocytin for intracellular labeling of recorded neurons and had resistances of between 60 and $100 \mathrm{M} \Omega$.

Neurotransmitter agonists or antagonists were typically applied with the pressure-pulse technique in which a brief pulse of pressure (10-250 msec; $200-350 \mathrm{kPa}$ ) was applied to the back of a broken microelectrode (1-4 $\mu \mathrm{m}$ tip diameter) to extrude $\sim 1-20 \mathrm{pl}$ of solution. Applications of glutamate and GABA were performed at varying locations and depths within the slice to determine the best response. Other agonists and antagonists were applied to the surface of the slice either within $50 \mu \mathrm{m}$ of the entry point of the recording electrode or as indicated in the figures. The latency for activation of neurons with local application of glutamate was estimated by performing extracellular multiple unit recordings adjacent to the glutamate-applying micropipette within the slice. These recordings revealed that pressure-pulse application of glutamate caused action potentials at a minimum latency of $20-25 \mathrm{msec}$, followed by an increase in the intensity of neuronal discharge peaking at $\sim 35-40 \mathrm{msec}$ Therefore, monosynaptic connections between neurons excited by local application of glutamate and recipient cells will have a minimum latency of 20-30 msec. This latency may be longer if the location of the excited neuron is not immediately adjacent to the local application of glutamate. The detection of monosynaptic connections was facilitated by the relative lack of polysynaptic excitatory connections between thalamocortical cells in the LGNd (Soltesz and Crunelli, 1992; Sanchez-Vives et al., 1996). The degree of activation of the PGN was typically varied by making incremental steps in the duration of the pulse of pressure applied to the glutamate application pipette. These durations were normalized for the purposes of illustration by dividing each by the duration of the maximal application plotted. In addition, the fast and slow GABA responses or IPSPs were also normalized to the peak amplitude generated for the purposes of illustration. We have demonstrated previously that there are no, or only very weak, functional connections between the perigeniculate and local circuit interneurons (Bal et al., 1995a,b), although PGN neurons do inhibit interlaminar PGN-like interneurons (Sanchez-Vives et al., 1996), as well as other PGN cells (Sanchez-Vives et al., 1997). These GABAergic to GABAergic neuronal connections seem to be purely inhibitory, and therefore the IPSPs induced in thalamocortical cells from application of glutamate in the PGN can be safely assumed to result from the release of GABA from PGN neurons.

When GABA antagonists were applied locally, we attempted to ensure that these drugs where confined to either the PGN or LGNd by making applications in small drops $(\sim 5-10 \mu \mathrm{m}$ in diameter $)$ on the anterior-most aspects of the PGN and by confining our intracellular recordings and drug applications to thalamocortical cells to lamina $\mathrm{A} 1, \sim 0.5 \mathrm{~mm}$ distant from the PGN.

Only those cells that exhibited stable resting membrane potentials negative to $-60 \mathrm{mV}$ and were capable of generating trains of action potentials with depolarization were included in this study. Data are reported as mean \pm SD. CGP35348 and CGP54626A were kind gifts of Novartis (Switzerland). All other drugs were obtained from Research Biochemicals (Natick, MA) or Sigma (St. Louis, MO).

\section{RESULTS}

Intracellular recordings were obtained from 184 thalamocortical neurons in either lamina A or A1 of the ferret LGNd. A representative sample of these cells exhibited an average resting membrane potential of $-64 \pm 4 \mathrm{mV}$ (mean $\pm \mathrm{SD} ; n=10)$ and an apparent input resistance to $0.1-0.4 \mathrm{nA}$ current pulses of $73 \pm 32$ $\mathrm{M} \Omega$. As reported previously (Bal et al., 1995a,b), during the generation of spindle waves thalamocortical neurons received barrages of IPSPs at a frequency of 6-10 Hz, whereas intracellular recordings from PGN neurons revealed barrages of EPSPs that activate repetitive low threshold $\mathrm{Ca}^{2+}$ spikes and bursts of action potentials (Fig. $1 A, B$ ). Bath application of the $\mathrm{GABA}_{\mathrm{A}}$ antagonists bicuculline methiodide $(20 \mu \mathrm{M})$ or picrotoxin $(10-20$ $\mu \mathrm{M})$ transformed spindle waves into slow, synchronized oscillations that were associated with more prolonged bursts of action potentials in both thalamocortical and PGN neurons (Fig. $1 C, D$ ). Close examination of the IPSPs generated in thalamocortical neurons during the generation of the spindle waves revealed that they have a latency to peak of $32.8( \pm 9.7 ; n=16) \mathrm{msec}$ and a duration of $170( \pm 18.4 ; n=16) \mathrm{msec}$ as measured from the onset of the IPSP (Fig. $1 B$ ). In contrast, the IPSPs occurring after the block of $\mathrm{GABA}_{\mathrm{A}}$ receptors had a latency to peak of $184.7 \mathrm{msec}$ ( $\pm 39.7 \mathrm{msec} ; n=16)$ and a duration of $454 \mathrm{msec}( \pm 67.0 \mathrm{msec}$; $n=16$ ) (Fig. 1D). Previously we have demonstrated that these slow IPSPs are mediated through the activation of $\mathrm{GABA}_{\mathrm{B}}$ receptors (Bal et al., 1995a,b). Comparing the action potential discharges generated by PGN neurons in normal and bicucullineor picrotoxin-containing solutions with the amplitude-time course of IPSPs in thalamocortical cells suggests that highfrequency and prolonged discharges in PGN neurons may be needed to strongly activate $\mathrm{GABA}_{\mathrm{B}}$ receptors, a prerequisite to the generation of the bicuculline-induced slow network oscillations (Bal et al., 1995a,b). Here we examine this possibility with intracellular recordings in thalamocortical cells while we activate the PGN to varying degrees with the local application of glutamate.

\section{Properties of GABAergic IPSPs activated by stimulation of the PGN}

Local activation of neurons in the PGN with the pressure-pulse application of glutamate activated a compound IPSP in thalamocortical cells at relatively short latency $(25-50 \mathrm{msec})$ followed by the repetitive barrages of IPSPs representative of the generation of a spindle wave (Fig. $2 A$ ). Activation of these IPSPs while the thalamocortical cell was depolarized or hyperpolarized to different membrane potentials (after the block of $\mathrm{GABA}_{\mathrm{B}}$ receptors with the local application of CGP 35348; 2 mM in micropipette) revealed that the presumed monosynaptic IPSPs exhibited a reversal potential of $-83.3 \pm 3.6 \mathrm{mV}(n=9)$, which was the same as the reversal potential for the spindle wave-associated IPSPs $(-83.4 \pm 3.0 \mathrm{mV} ; n=6)$ (Fig. $2 A)$. Local application of bicuculline methiodide $(0.2-0.4 \mathrm{~mm}$ in micropipette; $n=34)$, picrotoxin (0.5 $\mathrm{mm}$ in pipette; $n=9$ ), or SR 95531 ( $0.5 \mathrm{~mm}$ in pipette; $n=$ 


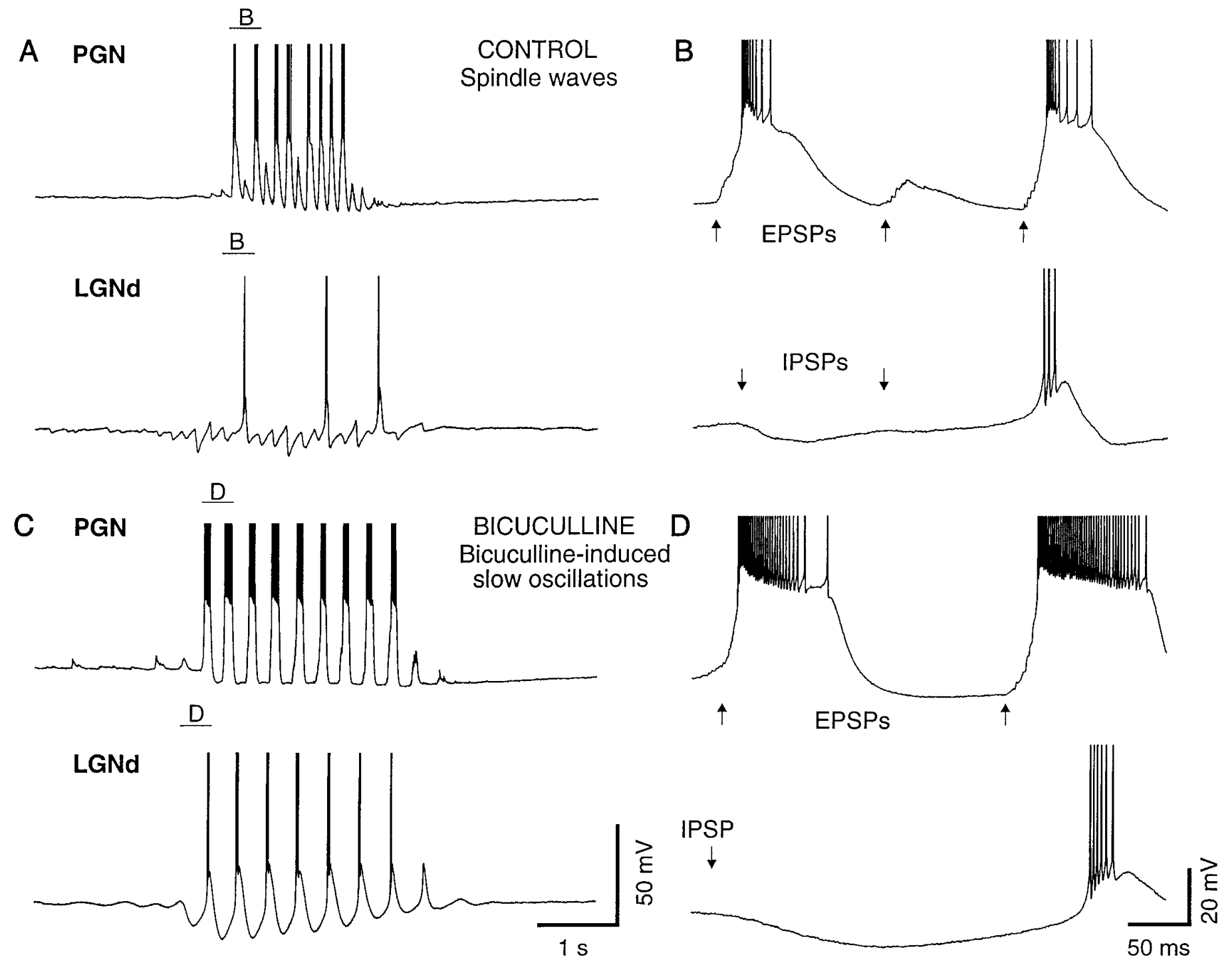

Figure 1. The block of $\mathrm{GABA}_{\mathrm{A}}$ receptors prolongs the bursts of action potentials in PGN cells and enhances activation of GABA $\mathrm{B}_{\mathrm{B}}$ receptors in thalamocortical neurons. $A$, Intracellular recordings from a PGN cell $\left(V_{m}=-75 \mathrm{mV}\right)$ and a thalamocortical neuron $\left(V_{m}=-72 \mathrm{mV}\right)$ in the LGNd during the generation of a spindle wave. The PGN neuron generates repetitive bursts of $8-10$ action potentials, and the thalamocortical cell exhibits phasic IPSPs that have a rapid rate of rise and a duration of $100-170 \mathrm{msec} . B$, Expansion of part of the recordings in $A$ for detail. Barrages of EPSPs and IPSPs are indicated. $C$, The bath application of bicuculline $(20 \mu \mathrm{M})$ results in the generation of a slowed oscillation characterized by the generation of prolonged discharges of 25-38 action potentials in the PGN neuron and slow $>300 \mathrm{msec}$ duration IPSPs in thalamocortical cells. $D$, Expansion of part of the traces in $C$ for detail. The PGN and LGNd cells were not recorded simultaneously.

2) to the region of the recorded thalamocortical cell abolished these evoked IPSPs, indicating that they were mediated by $\mathrm{GABA}_{\mathrm{A}}$ receptors (Fig. $2 A$ ). Increasing the duration of the glutamate application in the PGN, after the abolition of these IPSPs with bicuculline or picrotoxin and the washout of CGP35348, resulted in the activation of a slow IPSP (Fig. 2B). This IPSP reversed at an average membrane potential of $-96.7 \pm$ $7.7 \mathrm{mV}(n=8)$ and was blocked by local application of CGP 35348 ( $2 \mathrm{~mm}$ in micropipette), indicating that it was mediated by $\mathrm{GABA}_{\mathrm{B}}$ receptors.
These results suggest that the functional activation of $\mathrm{GABA}_{\mathrm{A}}$ and $\mathrm{GABA}_{\mathrm{B}}$ receptors in thalamocortical cells may require different intensities of discharge in PGN cells, which is regulated not only by the activity of excitatory afferents but also by the degree of inhibition from neighboring PGN neurons (Bal et al., 1995b; Sanchez-Vives et al., 1997). Here we examined further the functional effect of block of $\mathrm{GABA}_{\mathrm{A}}$ receptors in the PGN and LGNd on the generation of IPSPs in thalamocortical cells.

Gradual increases in the duration of glutamate application to the PGN resulted in steady increases in the peak amplitude and

Figure 2. Excitation of PGN neurons with the local application of glutamate activates both GABA $_{\mathrm{A}}$ and GABA $\mathrm{B}_{\mathrm{B}}$ receptor-mediated IPSPs in thalamocortical cells. $A$, Local application of glutamate in the PGN results in the activation of a rapid barrage of IPSPs followed by the generation of a spindle wave in a thalamocortical cell in lamina A1. Evoking these IPSPs while the cell is depolarized or hyperpolarized to different membrane potentials reveals that they reverse at $-86 \mathrm{mV}$. Local application of bicuculline in lamina A1 abolishes the evoked and spindle-associated IPSPs. The diagram at the bottom schematically illustrates the recording and drug-applying arrangement. $\mathrm{GABA}_{\mathrm{B}}$ receptors were blocked (Figure legend continues) 


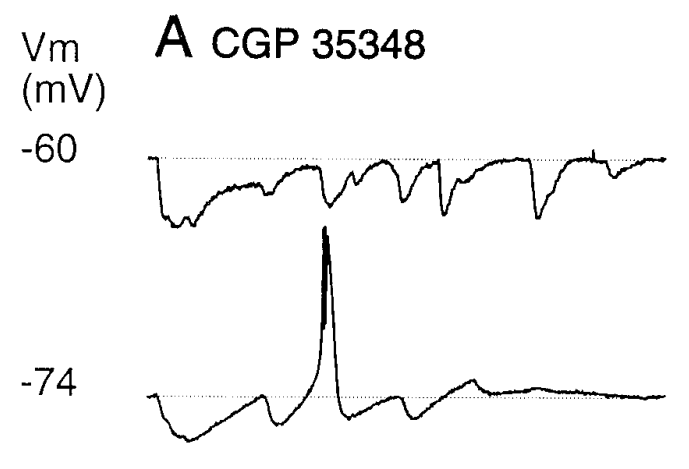

$-79$

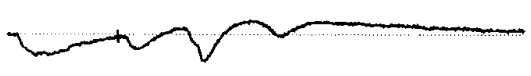

$-86$

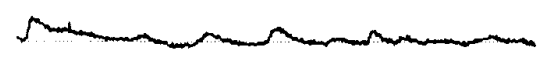

\section{+ Bicuculline in lamina A1}

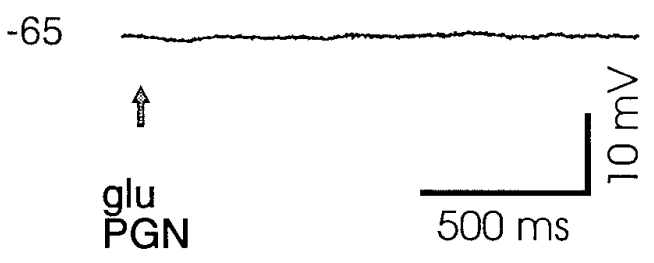

\section{Vm B Bicuculline \\ $(\mathrm{mV})$}

$-66$

$-73$

$-77$

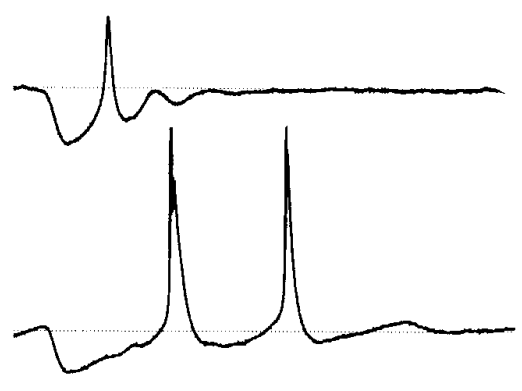

$-91$

$-103$

\section{+ CGP 35348 in lamina A1}

$-70$

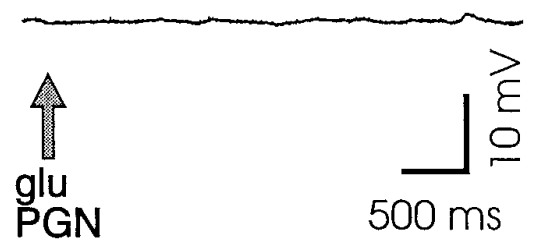

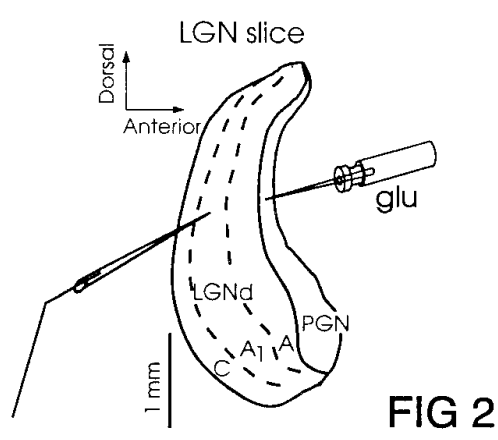

FIG 2
C

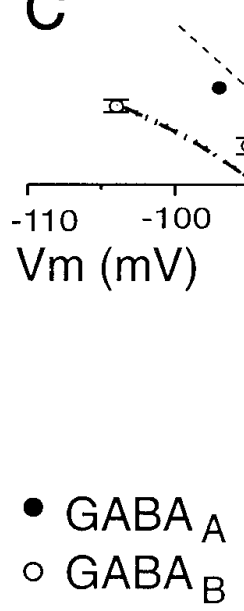

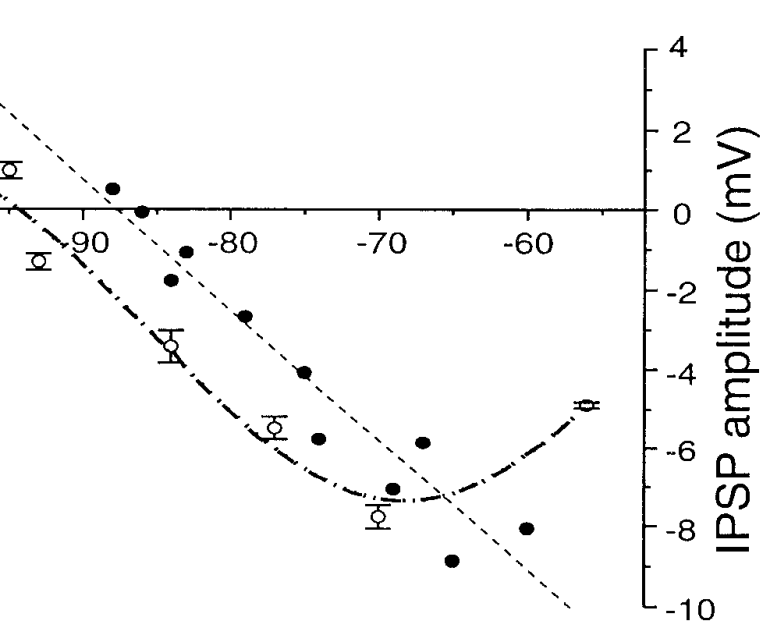

in this experiment with the local application of CGP35348 (2 mM in micropipette). $B$, Increasing the dose of glutamate application in the PGN after the block of $\mathrm{GABA}_{\mathrm{A}}$ receptors with bicuculline ( $400 \mu \mathrm{M}$ in micropipette) in lamina A1 results in the activation of a slow IPSP. This slow IPSP reverses at approximately $-95 \mathrm{mV}$ and is blocked by the local application of CGP35348. C, Graph illustrating the reversal potential for the fast and slow IPSPs in this thalamocortical neuron. All recordings were performed after the block of the hyperpolarization-activated cation current with the local application of $\mathrm{CsCl}$ ( $20 \mathrm{~mm}$ in micropipette). Note differences in time base for responses in $A$ and $B$. glu, Glutamate. 

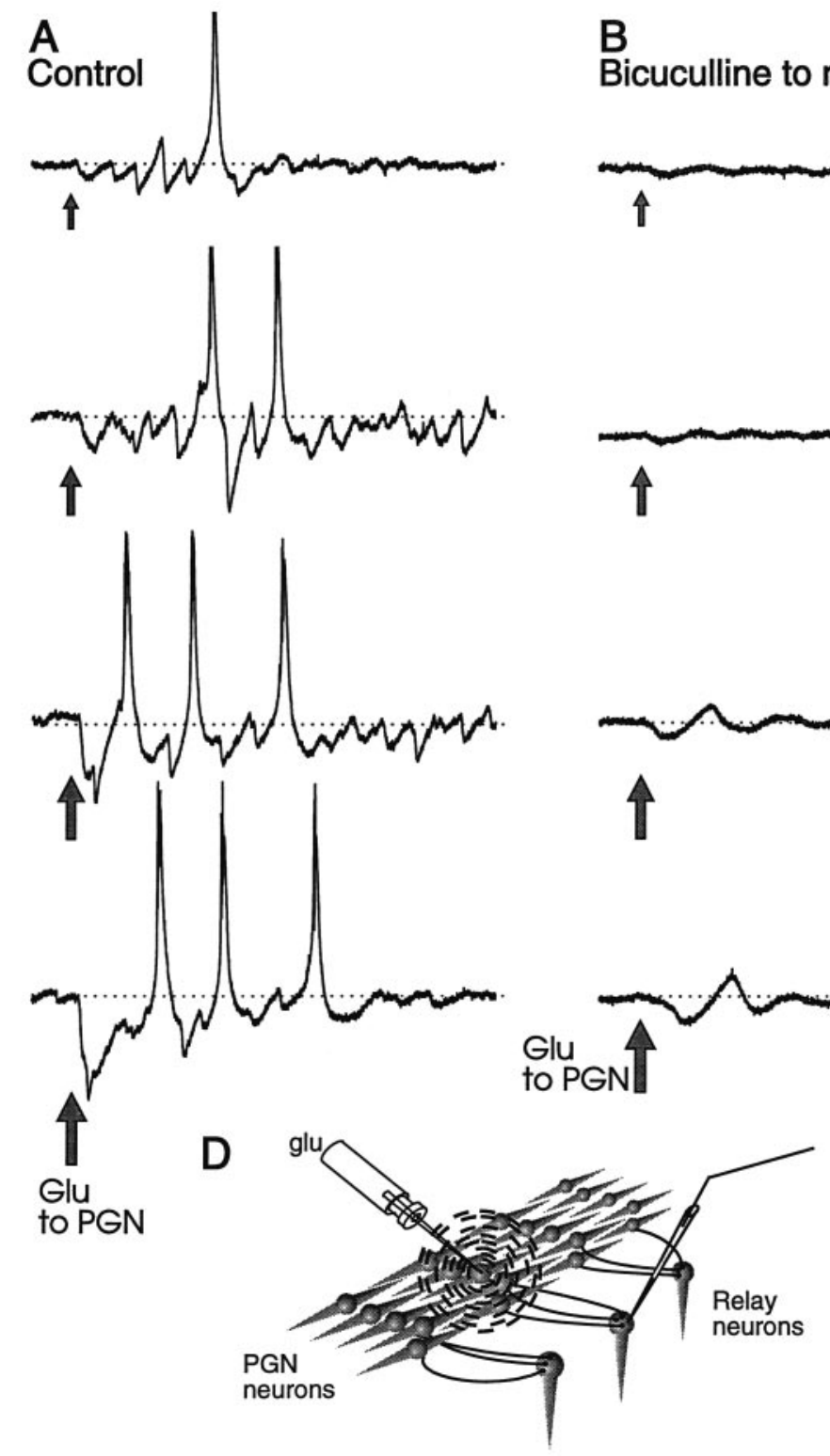
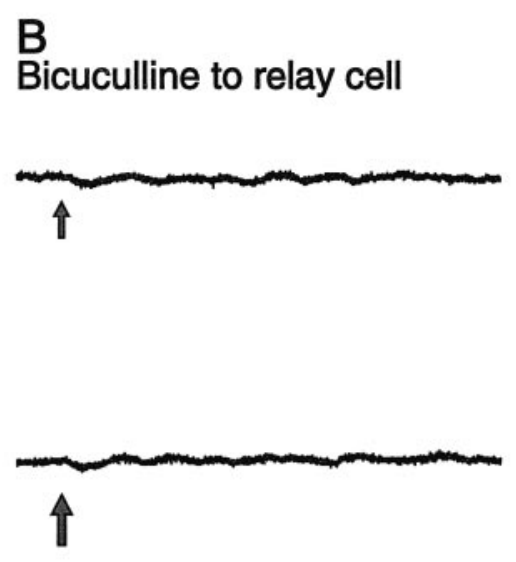

Figure 3. The amplitude and duration of PGN to thalamocortical IPSPs depends on GABAergic inhibition in both the thalamocortical and PGN laminae. $A$, Increasing the dose of application of glutamate (Glu) (indicated by increasing arrow size) in the PGN results in increasing amplitude of the initial evoked IPSP barrage in a thalamocortical cell recorded in lamina A1 $\left(V_{m}=-68 \mathrm{mV}\right)$. B, After the local application of bicuculline $($ Bic $)$ (400 $\mu \mathrm{M}$ in micropipette) to lamina A1, the glutamate applications to the PGN are repeated and activate slow IPSPs that are presumably mediated by GABA $\mathrm{B}_{\mathrm{B}}$ receptors. $C$, Local application of bicuculline to the PGN results in a substantial enhancement of the amplitude of the slow IPSPs evoked in thalamocortical cells by glutamate application in the PGN. In addition, these glutamate applications now activate the slow oscillation. $D, E$, Schematic diagram of the recording and drug-applying arrangement.

duration of evoked IPSP barrages in thalamocortical cells (Fig. $3 A$ ). Comparing the evoked and spindle-associated IPSPs before and after local application of bicuculline (200-400 $\mu \mathrm{M}$ in micropipette) to lamina A1 revealed that both IPSPs were mediated largely through the activation of $\mathrm{GABA}_{\mathrm{A}}$ receptors (Fig. $\left.3 A, B\right)$. After the block of $\mathrm{GABA}_{\mathrm{A}}$ receptors, a slow IPSP remained. These slow IPSPs were blocked by local application of the GABA $_{\mathrm{B}}$ antagonist CGP35348 $(n=8)$, indicating that they were mediated by $\mathrm{GABA}_{\mathrm{B}}$ receptors (see Fig. $5 F$, bottom). After the local blockade of $\mathrm{GABA}_{\mathrm{A}}$ receptors at the recorded thalamocortical cell $(n=45)$, the evoked IPSPs lasted only a few cycles and did not generate the rhythmic low threshold $\mathrm{Ca}^{2+}$ spikes typical of the slow oscillation that occurs after bath application of
$\mathrm{GABA}_{\mathrm{A}}$ antagonists (Fig. $3 B$ ). However, additional local application of bicuculline to the PGN in the region of the glutamateapplying electrode, and subsequent block of PGN lateral inhibition (Sanchez-Vives et al., 1997), resulted in the enhancement of evoked IPSPs and the development of bicuculline-induced slowed oscillations (Fig. $3 C)(n=21)$.

Examination of the effects of bicuculline application in the PGN before application of this antagonist in the LGNd revealed similar results. Local application of bicuculline $(200-400 \mu \mathrm{M}$ in micropipette) to the PGN, near the site of glutamate application, enhanced the evoked IPSPs in thalamocortical cells $(n=38)$ (Figs. 4A, $B, 5 G$ ). This enhancement was often most prominent at the lowest doses of glutamate application in the PGN and became 
A

\section{Control}

$$
\hat{\imath}
$$
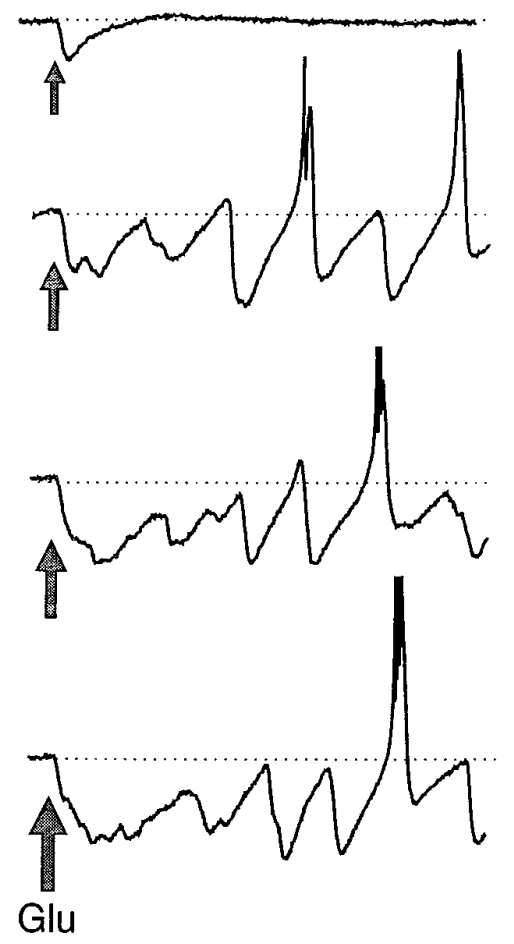

B

\section{Bicuculline in PGN}

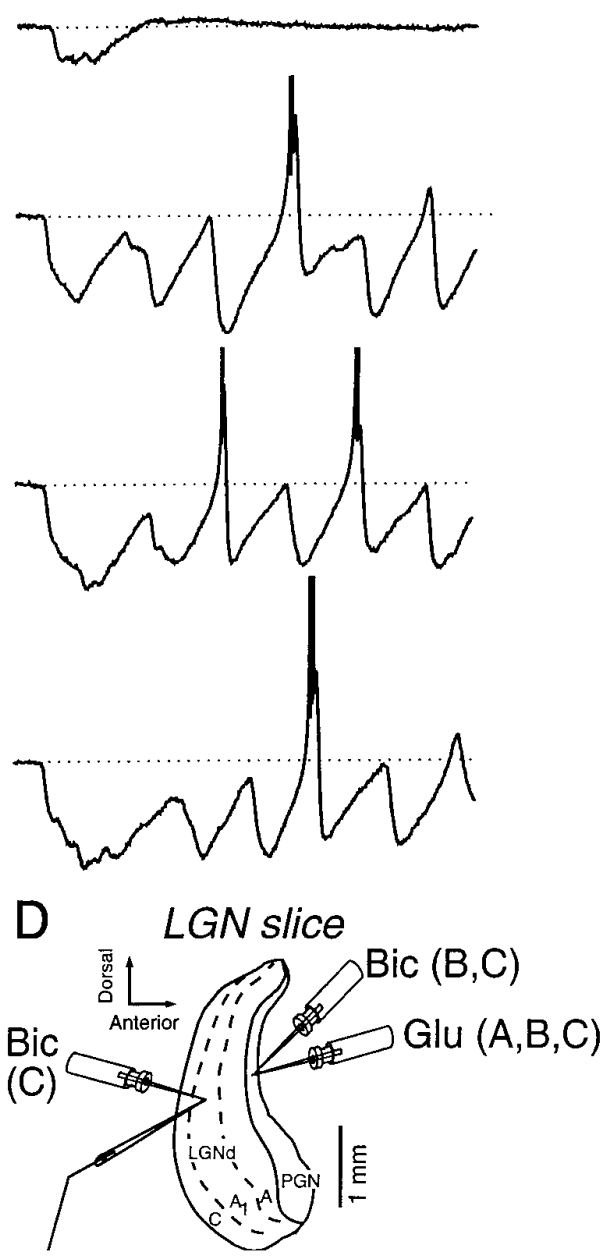

C

Bicuculline in PGN + relay

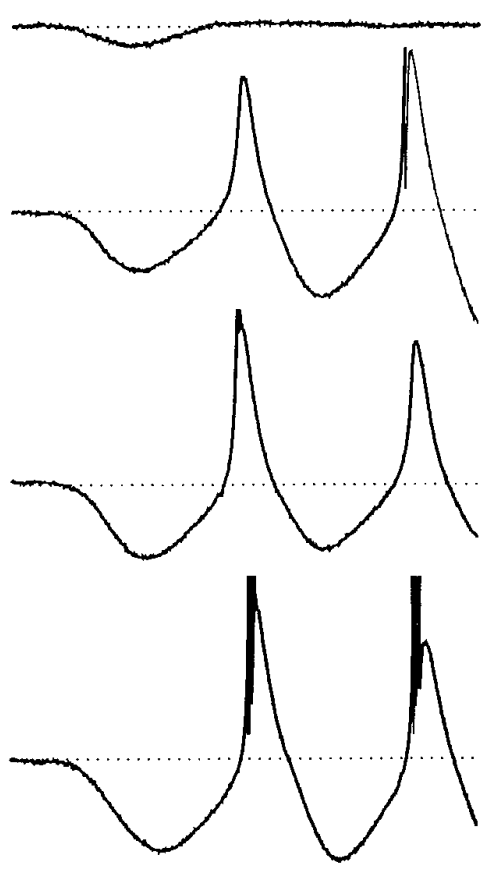

Figure 4. The generation of the bicuculline-induced slow oscillation requires the block of $\mathrm{GABA}_{\mathrm{A}}$ receptors in both the PGN and thalamocortical laminae. $A$, Same experiment as in Figure $3 A$, except in another cell. Increasing the dose of application of glutamate $(G l u)$ in the PGN results in increasing amplitude of IPSPs in the thalamocortical cell in lamina A1 $\left(V_{m}=-66 \mathrm{mV}\right) . B$, Local application of bicuculline (Bic) to the PGN results in a substantial enhancement of the evoked IPSPs at all levels of glutamate application. $C$, Local application of bicuculline to lamina A1 results in the abolition of the fast phases of the evoked IPSPs and reveals slow, presumed $\mathrm{GABA}_{\mathrm{B}}$ receptor-mediated IPSPs and the slow oscillation. $D$, Schematic diagram of experiment.

less apparent, although still present, with large applications of glutamate and large evoked IPSPs. Presumably this decreased enhancement results from a "ceiling effect" owing in part to the strong activation of PGN cells. The blockade of $\mathrm{GABA}_{\mathrm{A}}$ receptors in the PGN did not result in the generation of the bicucullineinduced slow oscillation (Fig. 4B), although the additional application of bicuculline to lamina $\mathrm{A} 1 \mathrm{did}$ result in the occurrence of the slowed oscillation (Fig. $4 C$ ). Together, these results suggest that the activation of $\mathrm{GABA}_{\mathrm{B}}$ receptor-mediated IPSPs in thalamocortical neurons that are large enough to result in the generation of rebound low threshold $\mathrm{Ca}^{2+}$ spikes requires the strong activation of the $\mathrm{PGN}$ and that $\mathrm{GABA}_{\mathrm{A}}$ receptors must be blocked in both the PGN and the LGNd for the generation of the bicuculline-induced slowed oscillation.

Additional support of this hypothesis was obtained with the bath application of CGP35348 to block $\mathrm{GABA}_{\mathrm{B}}$ receptors, followed by the local application of bicuculline (Fig. 5). Activation of the PGN with local application of glutamate after the bath application of the $\mathrm{GABA}_{\mathrm{B}}$ antagonist CGP35348 (1 mM) resulted in the activation of purely $\mathrm{GABA}_{\mathrm{A}}$ receptor-mediated IPSPs and spindle waves in thalamocortical cells (Fig. $5 A$ ). Local application of bicuculline ( $400 \mu \mathrm{M}$ in micropipette) to the PGN increased the amplitude of the initial evoked IPSP (Fig. 5B,G). Subsequent application of bicuculline to the region of the recorded thalamocortical cell completely blocked these IPSPs, confirming that they were mediated by $\mathrm{GABA}_{\mathrm{A}}$ receptors (Fig. $5 C$ ).

Removal of the bicuculline-applying pipette as well as the removal of CGP35348 from the bath reinstated evoked spindle oscillations (Fig. 5D). Subsequent application of bicuculline to both the PGN and lamina A1 transformed the evoked spindle waves into the 

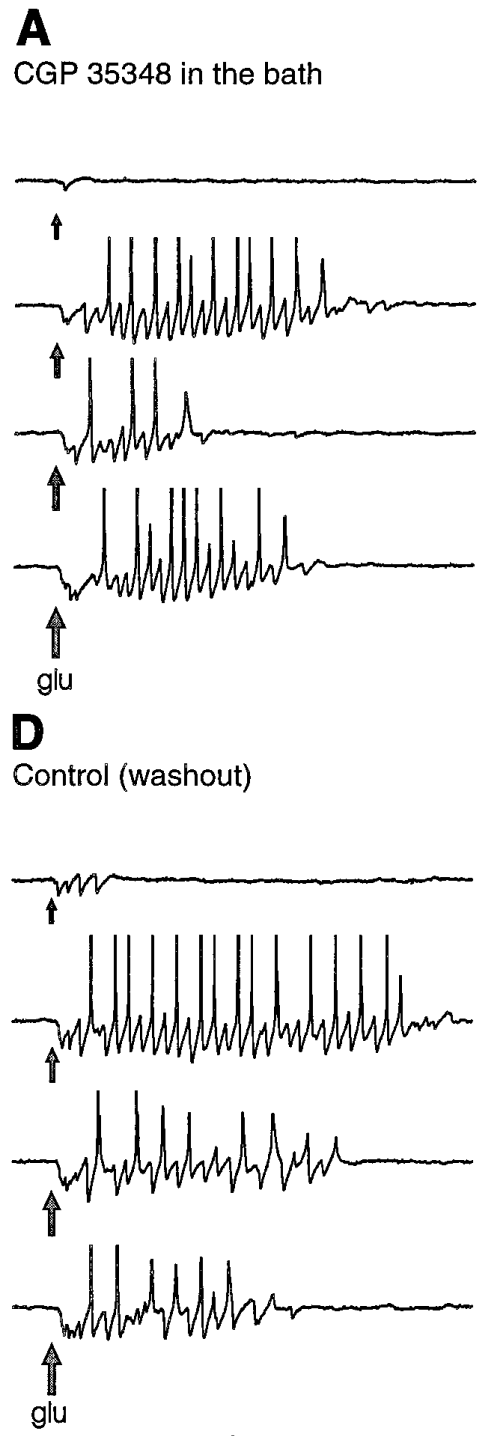

B

CGP 35348 in the bath + bicuculline in PGN

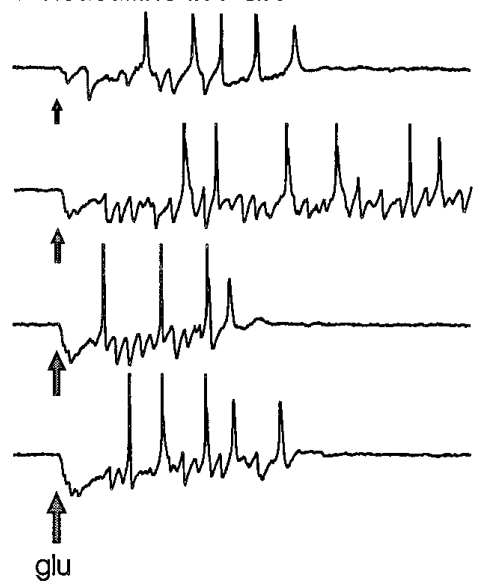

E

Bicuculline in PGN

+ Bicuculline to the relay cell

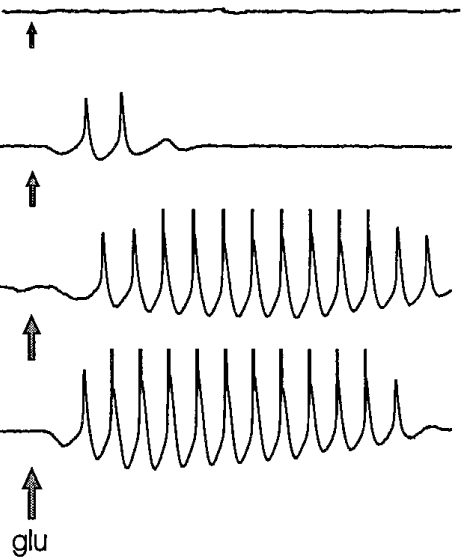

C

CGP 35348 in the bath

+ bicuculline in PGN

+ bicuculline to the relay cell

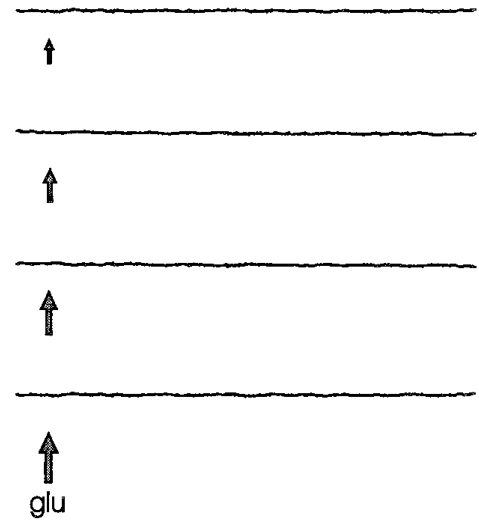

$\mathbf{F}$

Bicuculline in PGN

+ Bicuculline to the relay cell

+ CGP35348 to the relay cell

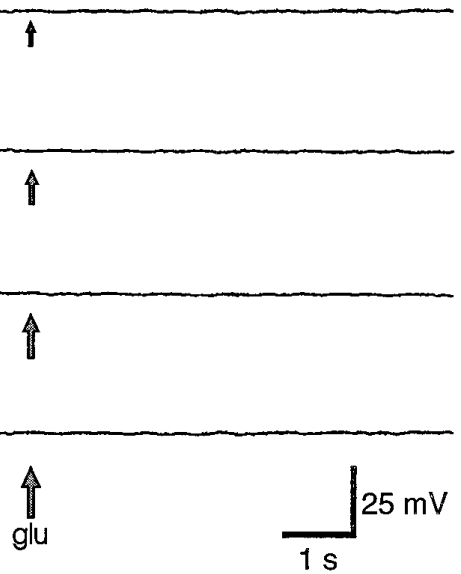

G

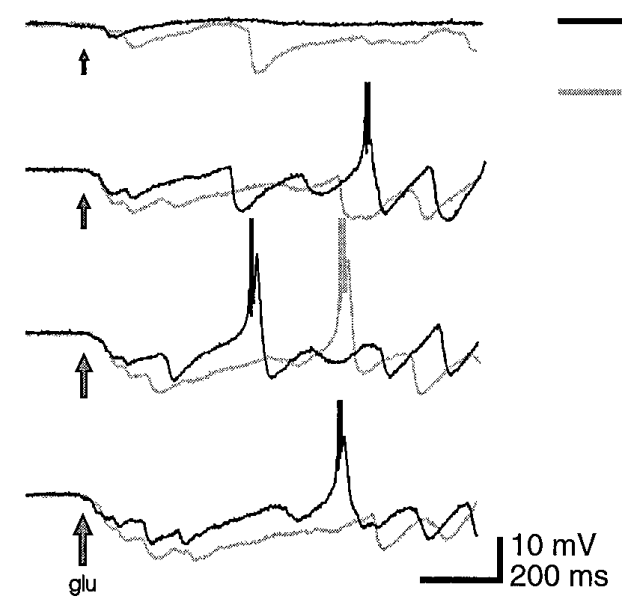

cgp 35348 in the bath

cgp 35348 in the bath + bicuculline in PGN

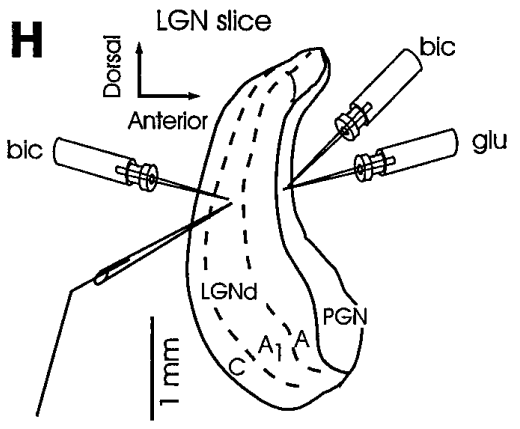

Figure 5. The involvement of $\mathrm{GABA}_{\mathrm{A}}$ and $\mathrm{GABA}_{\mathrm{B}}$ receptors in the generation of spindle waves and slowed oscillations. $A$, Application of increasing doses of glutamate $(g l u)$ to the PGN after the block of $\mathrm{GABA}_{\mathrm{B}}$ receptors with the bath application of CGP 35348 (1 mM) evokes normal-appearing spindle waves. $B$, Local application of bicuculline ( $400 \mu \mathrm{M}$ in micropipette) to the PGN results in an enhancement of the initial evoked IPSPs. $C$, Local application of bicuculline to lamina A1, after the application of bicuculline to the PGN, results in an abolition of all evoked IPSPs. $D$, Washout of bicuculline and CGP35348 from the slice results in the reinstatement of evoked IPSPs and spindle oscillations. $E$, Local application of bicuculline to both the PGN and lamina A1 results in the transformation of spindle waves into the slow oscillation. $F$, Local application of CGP 35348 (2 mM in micropipette) results in the abolition of all evoked IPSPs. $V_{m}=-67 \mathrm{mV}$ in all traces. $G$, Expanded and overlapped traces from $A$ and $B$, before and after application of bicuculline in the PGN. H, Schematic diagram of recording and drug application arrangement. bic, Bicuculline. 
bicuculline-induced slowed oscillation (Fig. $5 E$ ), which was subsequently blocked with local application of CGP35348 (2 mM in micropipette) to lamina $\mathrm{A} 1$, confirming that it is mediated through the activation of $\mathrm{GABA}_{\mathrm{B}}$ receptors (Fig. $5 F$ ).

These results confirm that the activation of the PGN can activate both $\mathrm{GABA}_{\mathrm{A}}$ and $\mathrm{GABA}_{\mathrm{B}}$ receptor-mediated IPSPs and suggest that the activation of large $G_{A B A_{B}}$ IPSPs may require a

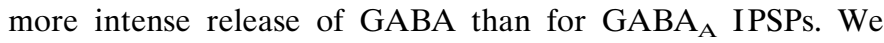
examined this possibility in several cells $(n=7)$ by generating input-output relationships for the fast IPSPs and bicucullineresistance slow IPSPs (Fig. 6). Incremental increases in the duration of the glutamate application in the PGN resulted in incremental increases in both the fast IPSPs and bicuculline-resistant slow IPSPs (Fig. 6 $A$ ). Plotting the peak amplitude of the fast and slow IPSPs before and after application of bicuculline revealed the input-output relations of these inhibitory potentials (Fig. $6 A c, A d)$. The amplitude of the fast, $\mathrm{GABA}_{\mathrm{A}}$ receptor-mediated IPSP was measured in normal bathing solution and therefore could contain a small contribution from the activation of $\mathrm{GABA}_{\mathrm{B}}$ receptors. However, this contribution is likely to be relatively small because GABA $_{B}$ IPSPs have a long latency (e.g., 25-50 msec) to onset, and the fast IPSPs peak relatively quickly (compare Fig. 6Aa, $A b)$. Examining the input-output relationship of the fast $\mathrm{GABA}_{\mathrm{A}}$ and slow $\mathrm{GABA}_{\mathrm{B}}$ IPSPs revealed that both exhibited a similar threshold for activation in 6 of 8 cells tested (Fig. 6), whereas in the remaining two cells, at the lowest levels of glutamate application in the PGN, a fast IPSP was evoked that was completely blocked by application of bicuculline (not shown). The activation of a $\mathrm{GABA}_{\mathrm{B}}$ receptor-mediated IPSP without activation of a $\mathrm{GABA}_{\mathrm{A}}$ receptor-mediated IPSP was never observed in normal solution. The most notable difference between the two responses was the relationship between their amplitudes and the duration of glutamate application (Fig. 6). Increasing the application of glutamate in the PGN increased the amplitude of both the fast and slow IPSPs, although the fast IPSP reached a large amplitude as well as obtained its maximal amplitude with lower doses of glutamate than did the slow IPSP (Fig. 6A). These results suggest that for a given amplitude, IPSPs mediated through $\mathrm{GABA}_{\mathrm{B}}$ receptors require a more intense release of GABA than do those mediated by $\mathrm{GABA}_{\mathrm{A}}$ receptors.

We performed similar input-output relationships for the response to exogenous application of GABA to thalamocortical neurons $(n=12)$ (Fig. $6 B)$. In normal bathing medium, the local application of GABA often evoked a complex of hyperpolarizing and depolarizing postsynaptic responses $(n=28$; not shown). Lowering the GABA-applying pipette closer to the depth of the recording electrode, which presumably was located in the soma, typically reduced or even abolished the depolarizing GABA response (Crunelli et al., 1988). The depolarizing GABA responses were also blocked by local application of acetazolamide (200 $\mu \mathrm{M}$ in micropipette), indicating that they represent GABAmediated increases in bicarbonate conductance (Staley et al., 1995). We have not yet observed similar depolarizing responses in the IPSPs induced by the activation of PGN neurons, despite intense activation of these cells with local application of glutamate. No changes in these IPSPs were observed when acetazolamide was applied to thalamocortical cells.

In the presence of acetazolamide, local application of increasing doses of GABA resulted in incremental increases in the activation of two distinct phases of hyperpolarization (Fig. 6Bb). Local application of the $\mathrm{GABA}_{\mathrm{A}}$ channel blocker picrotoxin $(500$ $\mu \mathrm{M}$ in micropipette) abolished the initial fast phase of these hyperpolarizing GABA responses, leaving a presumed $\mathrm{GABA}_{\mathrm{B}}$ receptor-mediated hyperpolarization (Fig. $6 B c$ ). Subtracting the responses obtained after picrotoxin application from those obtained before revealed the amplitude and time course of the $\mathrm{GABA}_{\mathrm{A}}$ receptor-mediated component (not shown). Comparing the presumed $\mathrm{GABA}_{\mathrm{B}}$ and $\mathrm{GABA}_{\mathrm{A}}$ components revealed that at all but the lowest level of GABA application, both of these receptors are activated. At the threshold level of GABA application, a small $(\sim 1 \mathrm{mV})$ hyperpolarization is evoked that is completely blocked by local application of picrotoxin (Fig. 6B).

\section{Presynaptic inhibition of GABA release in LGNd}

Previous investigations of GABAergic synapses have consistently revealed that the activation of presynaptic $\mathrm{GABA}_{\mathrm{B}}$ receptors results in the inhibition of GABA release (for review, see Bowery, 1989). Similarly, we found that the local application of the $\mathrm{GABA}_{\mathrm{B}}$ agonist baclofen (100-200 $\mu \mathrm{M}$ in micropipette) resulted in a pronounced reduction in the amplitude of evoked IPSPs in thalamocortical neurons $(n=10)$ (Fig. $7 A)$. In addition, the local application of baclofen also increased the apparent input conductance by $\sim 20-30 \%$, although this was too small to explain the $\sim 80 \%$ decrease in amplitude of the evoked IPSPs (Fig. 7). The local application of the $\mathrm{GABA}_{\mathrm{B}}$ receptor antagonist CGP35348 (2 $\mathrm{mm}$ in micropipette) reversed these effects of baclofen. Both the reduction in evoked IPSP amplitude as well as the hyperpolarization and increase in membrane conductance returned to normal (Fig. 7A). Interestingly, the local application of baclofen to the region of the PGN activated with glutamate application only slightly reduced or had no effect on the amplitude and duration of evoked IPSPs in thalamocortical cells (Fig. 7B). In the accompanying paper (Sanchez-Vives et al., 1997), we demonstrate that the activation of $\mathrm{GABA}_{\mathrm{B}}$ receptors hyperpolarizes perigeniculate neurons. Presumably the glutamate-induced depolarization in PGN cells, which probably was facilitated by the low threshold $\mathrm{Ca}^{2+}$ current, was large enough to overcome this baclofeninduced hyperpolarization.

To control for the indirect decrement of GABAergic IPSPs through changes in postsynaptic membrane conductance, inhibitory postsynaptic currents were recorded with single-electrode voltage clamp in thalamocortical neurons with electrodes filled with $2 \mathrm{M} \mathrm{CsAc}$ to reduce $\mathrm{K}^{+}$conductances $(n=4)$ (Fig. 8). Under these conditions, the local application of baclofen to lamina A1 of the LGNd resulted in a small outward current and inhibited both glutamate-evoked and spindle-associated IPSCs in thalamocortical cells (Fig. 8A,B), without affecting the intensity of extracellularly recorded glutamate-evoked discharge in the PGN (Fig. 8).

The possibility that the activation of $\mathrm{GABA}_{\mathrm{B}}$ receptors occurs endogenously and reduces the amplitude of IPSPs in thalamocortical cells was examined by applying CGP35348 to lamina A while recording evoked or spindle wave-associated IPSPs or IPSCs $(n=6)$ (Fig. 9). Local application of CGP35348 (2 $\mathrm{mm}$ in micropipette) enhanced the amplitude of evoked IPSPs (Fig. $9 A, B)$ as well as evoked IPSCs (Fig. 9C,D). In addition, the local application of CGP35348 also enhanced spindle wave-associated IPSCs (Fig. 9). In one cell that exhibited a large number of spontaneous IPSCs, application of CGP35348 also increased the amplitude of these spontaneous events (Fig. 9E-G).

\section{DISCUSSION}

Investigations into the inhibitory influence of the GABAergic neurons of the thalamic reticular or perigeniculate nuclei have repeatedly demonstrated that these cells activate $\mathrm{GABA}_{\mathrm{A}}$ recep- 


\section{A IPSPs (Glu to PGN)}

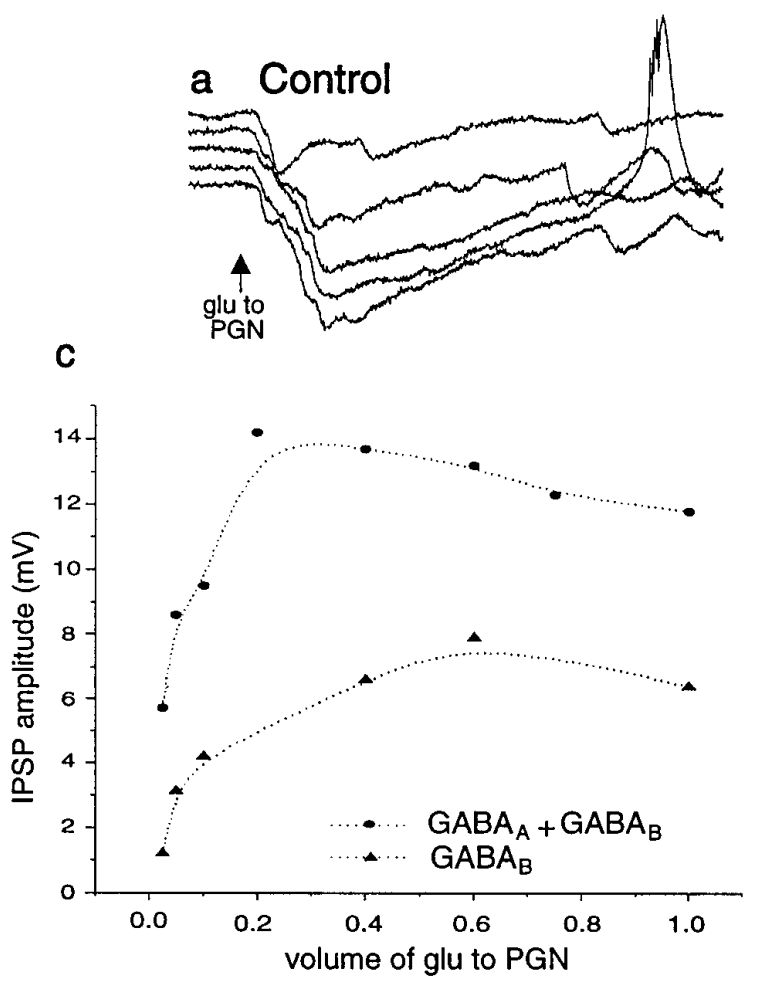

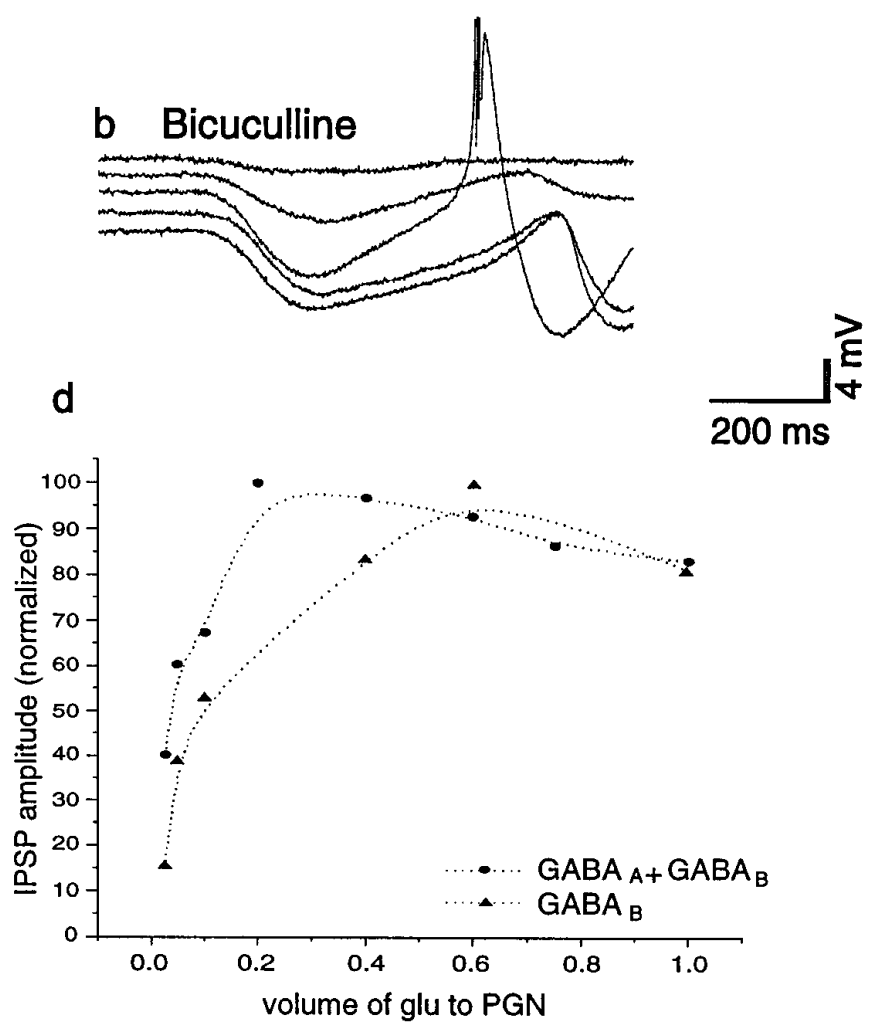

B GABA response
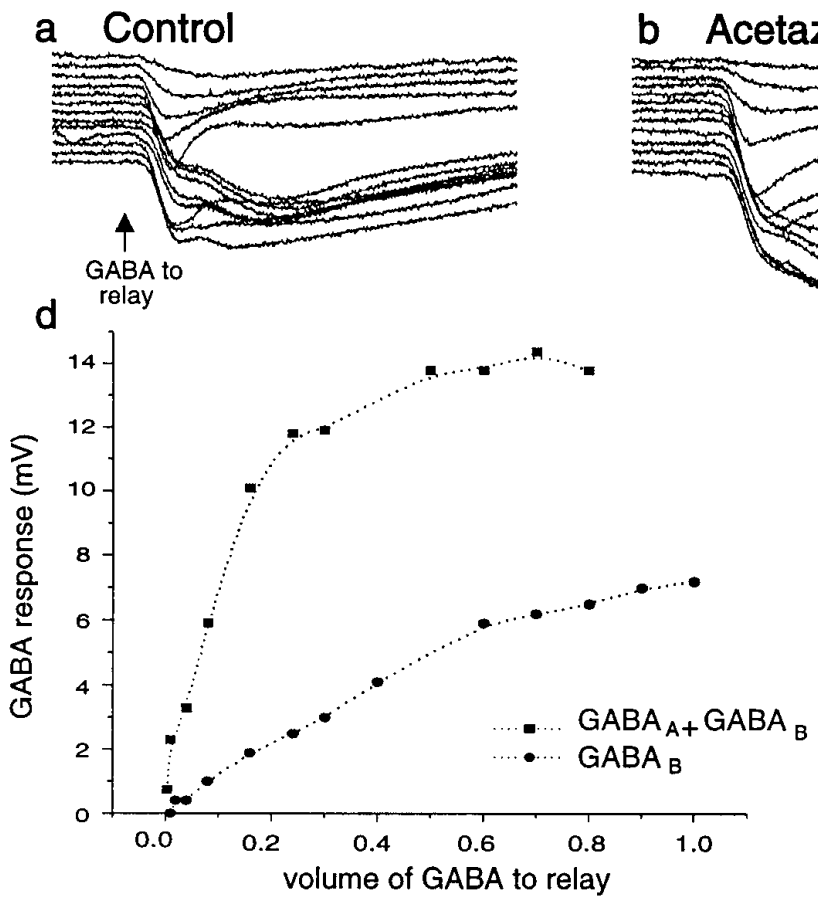

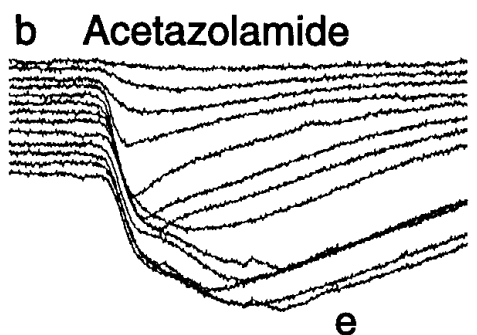

C Picrotoxin

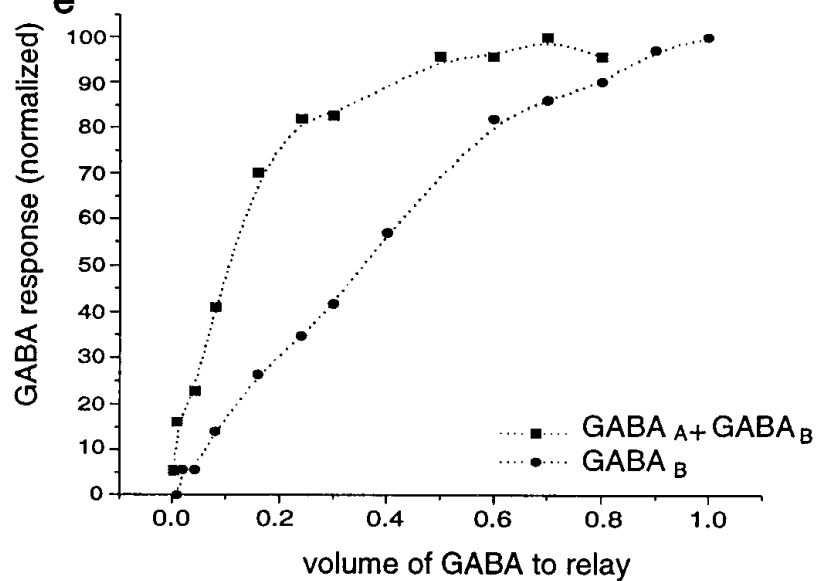

Figure 6. Comparison of the properties of inhibitory responses induced in thalamocortical cells by glutamate application in the PGN versus direct GABA application. $A$, IPSPs of increasing amplitudes evoked in a thalamocortical cell by the application of glutamate ( $g l u$ ) to the PGN. The duration of glutamate applications was made progressively longer and subsequently generated more intense inhibition. $A a$, Bicuculline (400 $\mu \mathrm{M}$ in micropipette) was applied locally to the PGN, blocking lateral inhibition between PGN cells. Under these conditions, the same volume of glutamate induced an IPSP of larger amplitude and duration in the recorded thalamocortical cell. $A b$, Application of bicuculline to the thalamocortical cell reveals the isolated $\mathrm{GABA}_{\mathrm{B}}$ component. Note that the latency of the response is longer for the activation of GABA $\mathrm{B}_{\mathrm{B}}$ receptors than for (Figure legend continues) 
A

Control

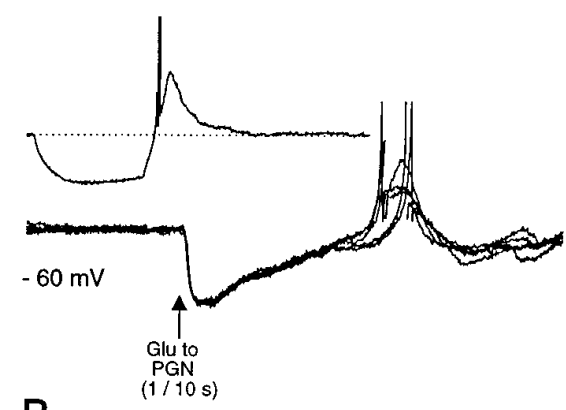

B

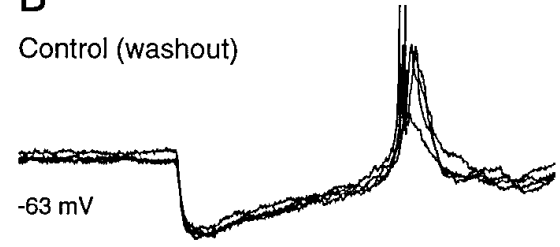

Baclofen to relay

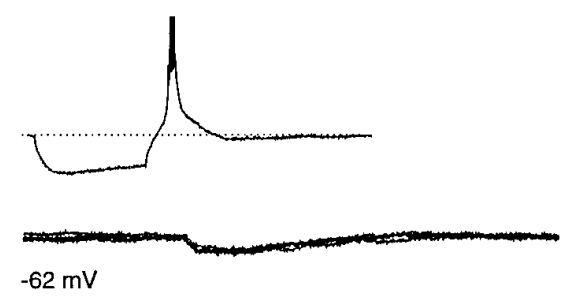

$-62 \mathrm{mV}$
CGP 35348 to relay (gradual recovery)

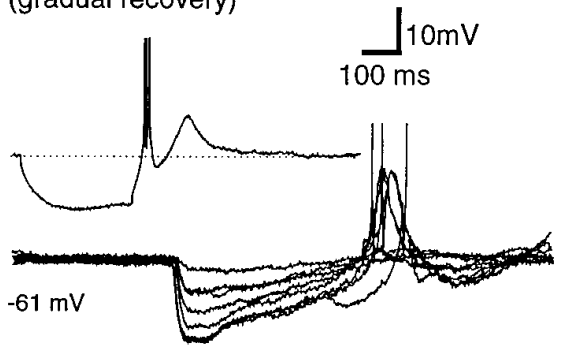

Figure 7. Activation of $\mathrm{GABA}_{\mathrm{B}}$ receptors results in a large reduction in the evoked IPSP in thalamocortical cells. $A$, Evoked IPSPs and rebound low threshold $\mathrm{Ca}^{2+}$ spike in a thalamocortical cell in response to glutamate $(G l u)$ application in the PGN. Above is the response of the cell to the injection of a $-0.15 \mathrm{nA}, 300 \mathrm{msec}$ hyperpolarizing current pulse. The local application of the $\mathrm{GABA}_{\mathrm{B}}$ receptor agonist baclofen (200 $\mu \mathrm{M}$ in micropipette) to the region of the recorded thalamocortical cell results in a large reduction in the amplitude of the evoked IPSP and a smaller reduction in the apparent input resistance of the cell. The cell was depolarized back to $-62 \mathrm{mV}$ after the application of baclofen. Local application of CGP 35348 ( $2 \mathrm{~mm}$ in micropipette) results in the gradual reinstatement of the full IPSP. Superimposed traces correspond to successive applications of glutamate (1/10 sec) during the recovery. $B$, The local application of baclofen in the PGN does not reduce the amplitude of the evoked IPSP in the thalamocortical cells, indicating that the effect of baclofen when applied to lamina A did not result from inhibition of PGN cells.

tors on thalamocortical cells (Thomson, 1988; Shosaku et al., 1989; Huguenard and Prince, 1994; Warren et al., 1994; Ulrich and Huguenard, 1995). The activation of $\mathrm{Cl}^{-}$-dependent IPSPs and/or $\mathrm{GABA}_{\mathrm{A}}$ receptors is particularly prominent and important to the generation of spindle waves during slow wave sleep (Andersen and Sears, 1964; Deschênes et al., 1984; Bal et al., 1995a,b). Burst firing in thalamic reticular and perigeniculate neurons activates IPSPs in thalamocortical cells that are of sufficient amplitude and duration to result in the generation of rebound low threshold $\mathrm{Ca}^{2+}$ spikes. The generation of these $\mathrm{Ca}^{2+}$ spikes leads to the activation of a burst of action potentials in thalamocortical cells and subsequently the excitation once again of the thalamic reticular/perigeniculate neurons (Steriade et al., 1993; Bal et al., 1995a,b). Surprisingly, the antagonism of $\mathrm{GABA}_{\mathrm{B}}$ receptors in vitro does not have marked effects on the generation of spindle waves, suggesting that the activation of these receptors is not essential to the generation of this normal sleep rhythm (Bal et al., 1995a,b) (see also Fig. 5).

Additional evidence, however, suggests that the strong activation of thalamic reticular/perigeniculate GABAergic neurons may also generate slow $\mathrm{K}^{+}$-mediated IPSPs through binding to
$\mathrm{GABA}_{\mathrm{B}}$ receptors (Huguenard and Prince, 1994; Bal et al., 1995a,b; Kim et al., 1997) and that the activation of $\mathrm{GABA}_{\mathrm{B}}$ receptors may be particularly important to the generation of some forms of generalized spike-and-wave seizures (Hosford et al., 1992; Snead, 1992). In particular, the bath application of the $\mathrm{GABA}_{\mathrm{A}}$ receptor antagonist bicuculline transforms normal spindle waves in vitro into slow, robust $1-4 \mathrm{~Hz}$ oscillations in which perigeniculate and thalamocortical neurons generate strong repetitive bursts of action potentials (Bal et al., 1995a,b). We have suggested previously that a key event in this transformation is the generation of strong bursts of action potentials in PGN neurons owing to disinhibition of these cells from one another (von Krosigk et al., 1993; Bal et al., 1995a,b).

Here we demonstrate that the PGN can inhibit thalamocortical cells of the ferret LGNd and other perigeniculate cells (SanchezVives et al., 1997) through the activation of both $\mathrm{GABA}_{\mathrm{A}}$ and $\mathrm{GABA}_{\mathrm{B}}$ receptors. Functionally, the activation of $\mathrm{GABA}_{\mathrm{A}}$ receptors after the generation of burst firing in even a single well connected PGN neuron is capable of generating a rebound low threshold $\mathrm{Ca}^{2+}$ spike and burst of action potentials in thalamocortical cells (Bal et al., 1995b; Kim et al., 1995, 1997; Bal and

\section{$\leftarrow$}

the activation of $\mathrm{GABA}_{\mathrm{A}} \cdot A c$, Relationship between IPSP amplitude and the duration of the glutamate application to PGN. The control situation shown in $A a$ is represented by circles, and pure $\mathrm{GABA}_{\mathrm{B}}$ activation is denoted by triangles. Ad, Comparison of the combined evoked GABA and GABA $_{\mathrm{B}} \mathrm{IPSP}_{\mathrm{A}}$ versus the $\mathrm{GABA}_{\mathrm{B}}$ IPSP only after normalization of each to their maximal amplitude. $B$, Application of GABA to thalamocortical neurons activates both $\mathrm{GABA}_{\mathrm{A}}$ and $\mathrm{GABA}_{\mathrm{B}}$ receptors. $B a$, The local application of increasing doses of GABA to a thalamocortical neuron in lamina A1 results in two distinct phases of hyperpolarization that increase in amplitude and duration with increasing doses. $B b$, Local application of acetazolamide (200 $\mu \mathrm{M}$ in micropipette) enhances the hyperpolarizing responses, suggesting that these overlapped with depolarizing components (see text). $B c$, Local application of picrotoxin (200 $\mu \mathrm{M}$ in micropipette) abolishes the fast hyperpolarizing phase. $B d$, Relationship between the amplitude of the inhibition and the normalized volume of GABA applied to the thalamocortical cell. $B e$, Same plot as in $B d$, but the amplitude of the GABA response has been normalized. All data obtained from the same thalamocortical cell at $V_{m}=-70 \mathrm{mV}$. Volume of glutamate and GABA were plotted as normalized values according to the duration of the pulse of pressure applied to the drug-applying pipette, with 1.0 being the longest duration application examined. The amplitude of the responses was measured at the peak. 


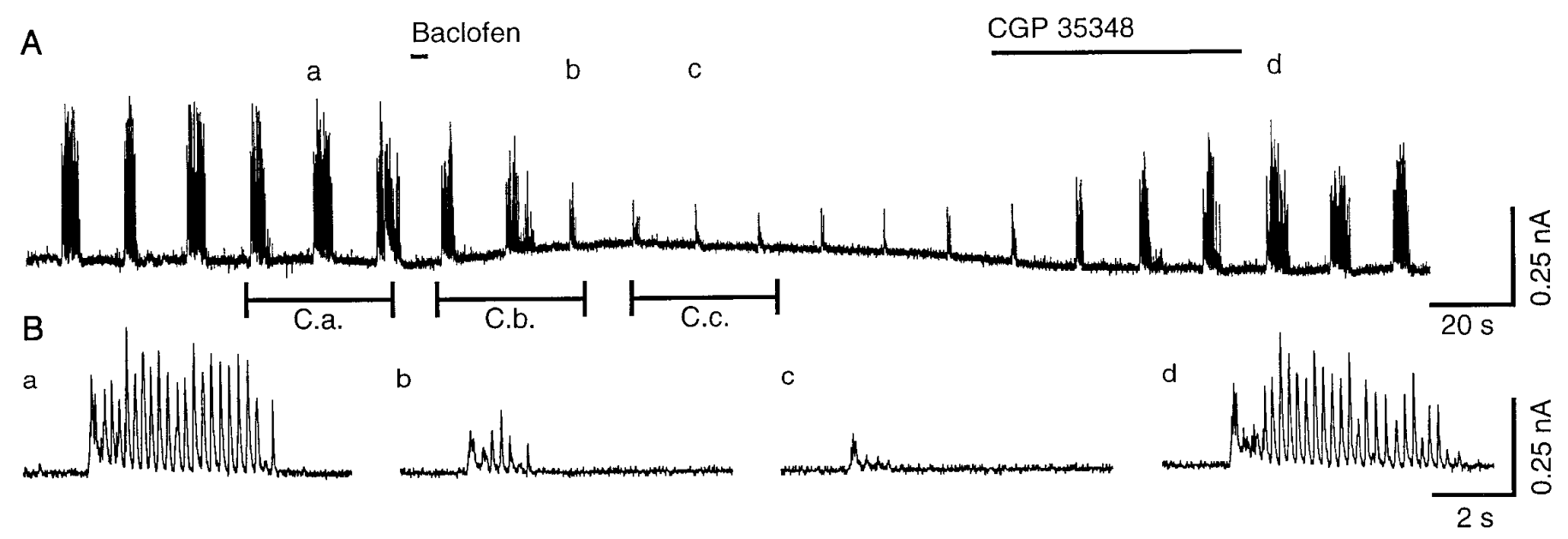

\section{PSTH of the PGN discharge}
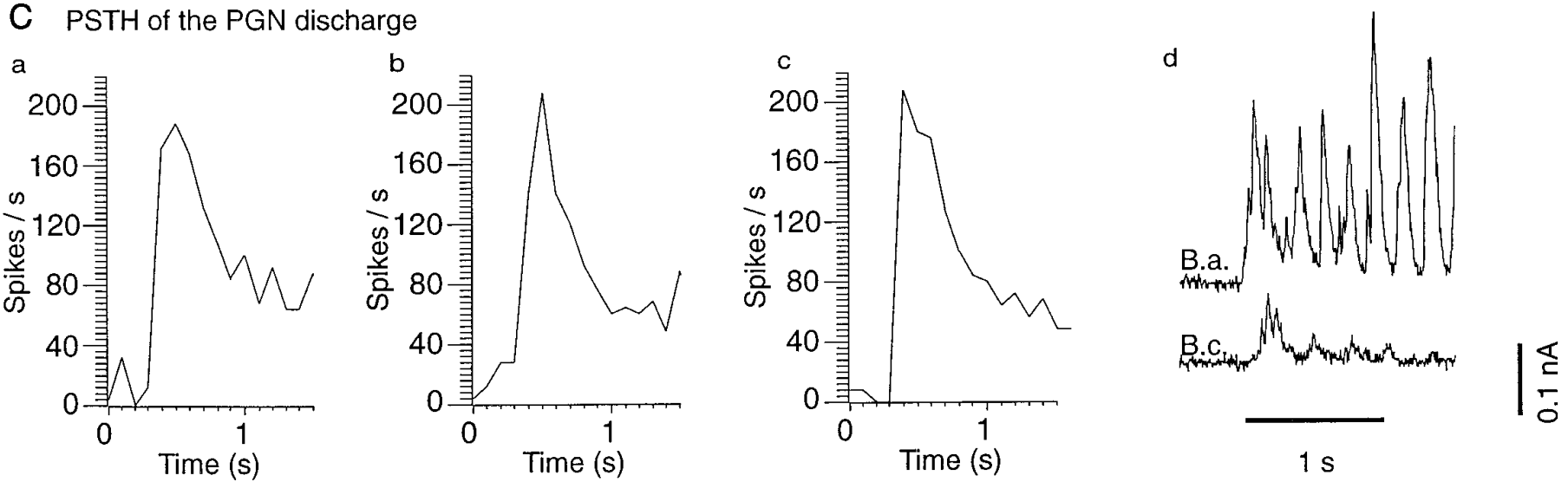

Figure 8. Activation of $\mathrm{GABA}_{\mathrm{B}}$ receptors results in the suppression of evoked and spindle-associated IPSCs in thalamocortical cells. $A$, IPSCs recorded in a thalamocortical cell with a microelectrode filled with $2 \mathrm{M} \mathrm{CsAc}$ and held at $-59 \mathrm{mV}$. Each barrage of IPSCs represents the generation of a spindle wave and was evoked with the local application of glutamate in the PGN. Application of baclofen (100 $\mu \mathrm{M}$ in the micropipette) results in a large reduction in the amplitude of the initial evoked IPSC as well as the generation of spindle wave-associated IPSCs. Local application of CGP 35348 reversed these effects. $B$, Expansion of spindle wave-associated IPSCs before and after application of baclofen and after recovery with application of CGP 35348. $C$, Peristimulus time histogram (PSTH) of multiple unit activity in the PGN evoked by glutamate before and after application of baclofen in the LGNd. The application of baclofen to the LGNd did not affect the activity evoked in PGN cells, indicating that the reduction in the IPSCs is not caused by a decrease in the evoked activity of PGN cells. Time 0 corresponds to the trigger that initiated the glutamate application. Each of the PSTHs $(a, b, c)$ is the average of the discharge of PGN during three glutamate applications as indicated in $A$ (C.a., C.b., C.c.). In $d$ is shown the expanded recording of the evoked IPSCs from the thalamocortical cell before and after application of baclofen (B.a., B.c.), with the same temporal scale as the PSTHs.

McCormick, 1996). This does not seem to be the case for the activation of $\mathrm{GABA}_{\mathrm{B}}$ receptors (Kim et al., 1997). This result confirms our previous suggestion that the activation of the bicuculline-induced 2-4 Hz oscillation requires the generation of synchronized prolonged burst discharges in a number of PGN neurons (Bal et al., 1995a,b). However, our present results also indicate that the disinhibition of PGN cells from one another is not sufficient for the generation of this abnormal activity.

We found that $\mathrm{GABA}_{\mathrm{A}}$ receptors must be blocked in both the PGN and the A-laminae for the bicuculline-induced slowed activity to be generated. Block of $\mathrm{GABA}_{\mathrm{A}}$ receptors in the Alaminae alone resulted in the abolition of spindle waves in that region without the appearance of the bicuculline-induced slow oscillation. This result is as expected, because the IPSPs occurring during the generation of spindle waves are mediated largely through the activation of $\mathrm{GABA}_{\mathrm{A}}$ receptors. Block of $\mathrm{GABA}_{\mathrm{A}}$ receptors in the PGN alone, however, also did not result in the generation of the bicuculline-induced slowed oscillation, but rather resulted in an enhancement of the amplitude and duration of IPSPs that result after activation of the PGN. This enhance- ment did not disrupt the generation of spindle waves. Only when $\mathrm{GABA}_{\mathrm{A}}$ receptors were subsequently blocked in the A-laminae were the bicuculline-induced slowed oscillations apparent (Fig. 4). This result suggests that the presence of strong $\mathrm{GABA}_{\mathrm{A}}$ receptor-mediated components in the PGN-evoked IPSPs in thalamocortical cells prevents the generation of the bicucullineinduced slowed oscillation, even after the block of $\mathrm{GABA}_{\mathrm{A}}$ re-

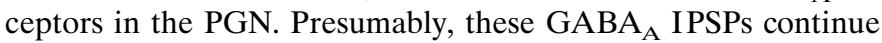
to generate rebound low threshold $\mathrm{Ca}^{2+}$ spikes at a latency that is approximately normal (e.g., 100-160 msec) (Bal et al., 1995a,b). With the block of $\mathrm{GABA}_{\mathrm{A}}$ receptors at the thalamocortical cells, only the slow $\mathrm{GABA}_{\mathrm{B}}$ receptor-mediated IPSPs remains. The prolonged time course ( $250-450 \mathrm{msec})$ of these IPSPs then forces the interaction between the PGN and thalamocortical cells to slow to $\sim 2-4 \mathrm{~Hz}$, which matches the intrinsic frequency with which single thalamocortical cells prefer to generate rhythmic low threshold $\mathrm{Ca}^{2+}$ spikes (McCormick and Pape, 1990). We propose that the slowing of the network oscillation to one that matches the intrinsic frequencies of thalamocortical cells is a key event that leads to the generation of this "paroxysmal" activity. 


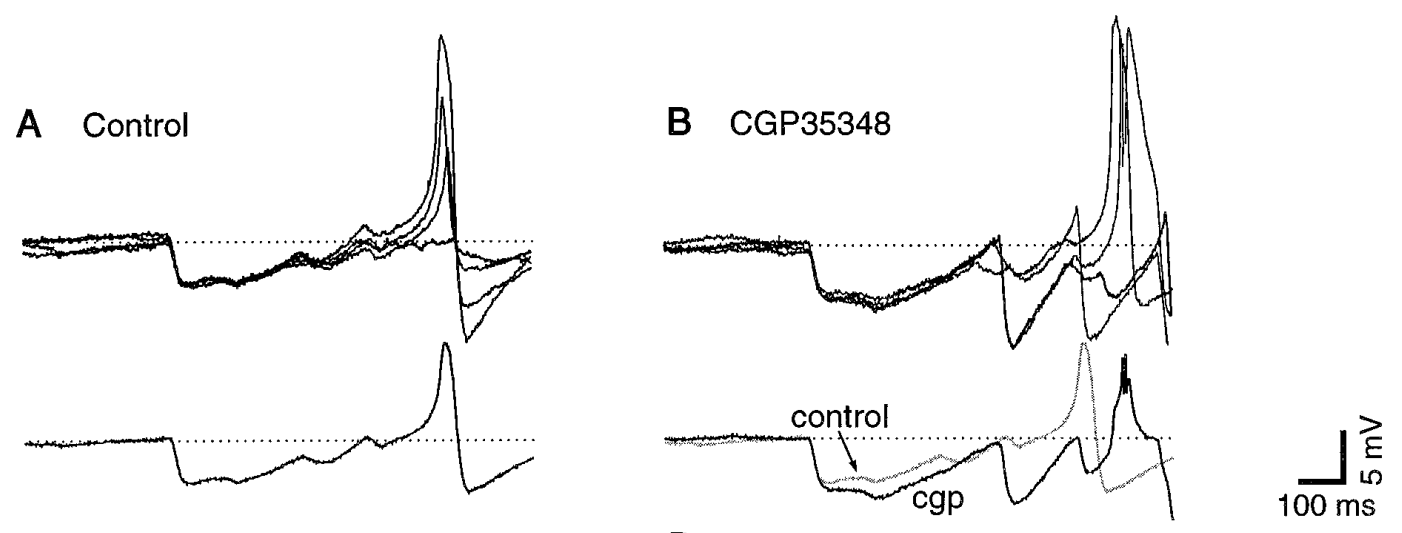

C Control

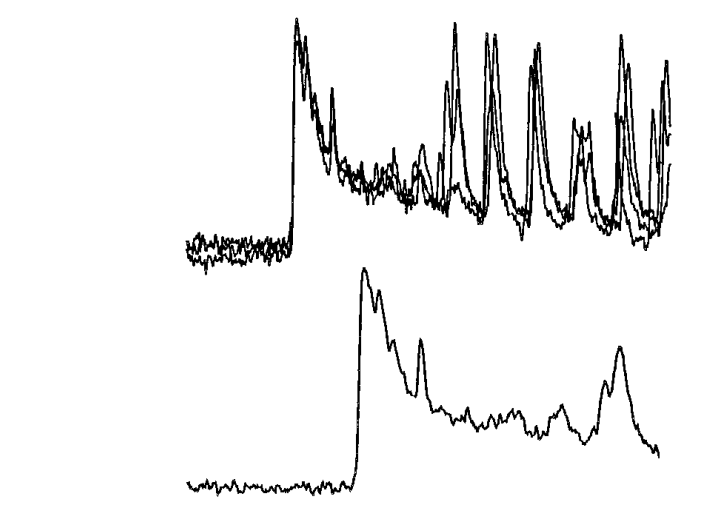

D CGP35348
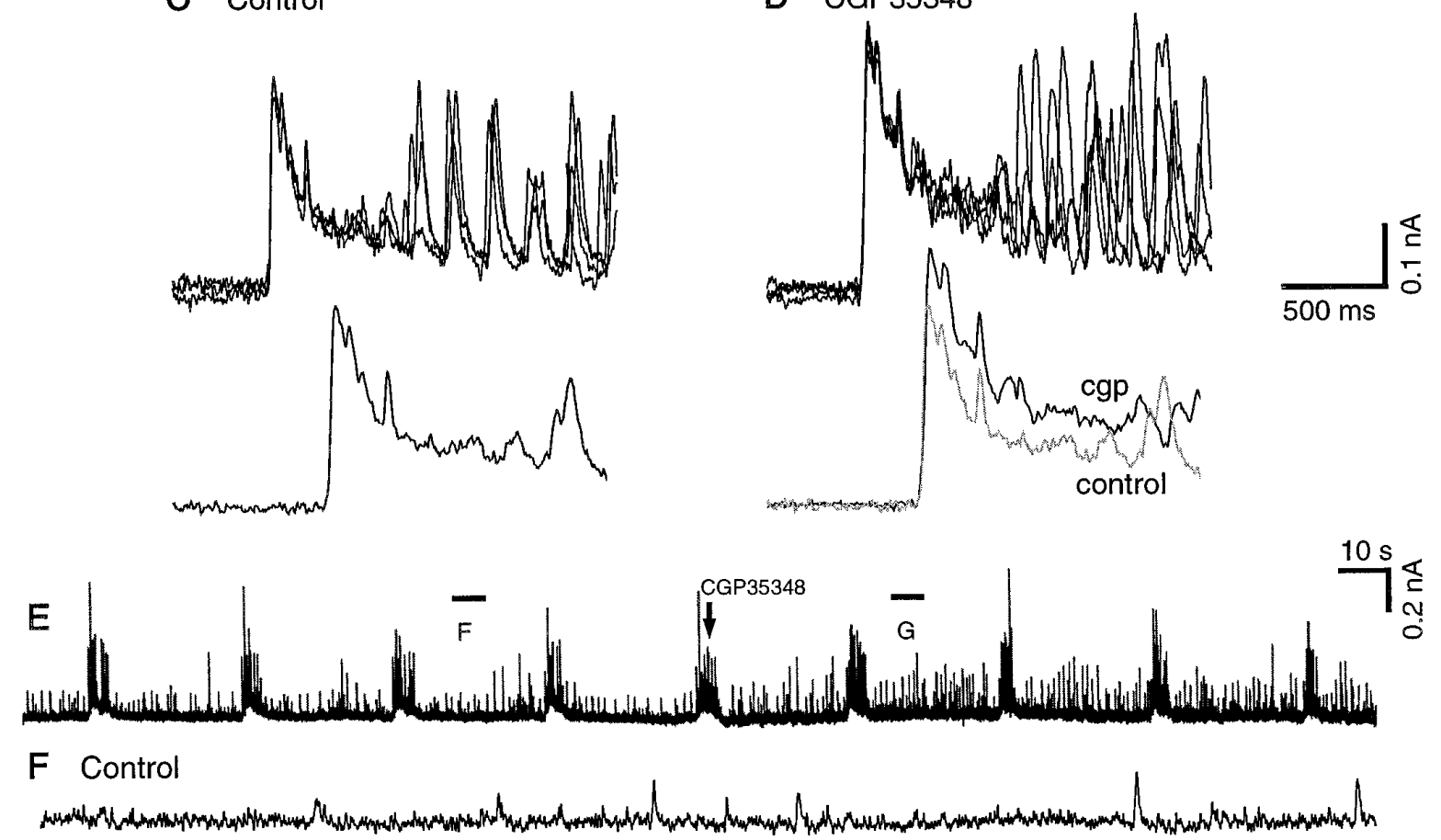

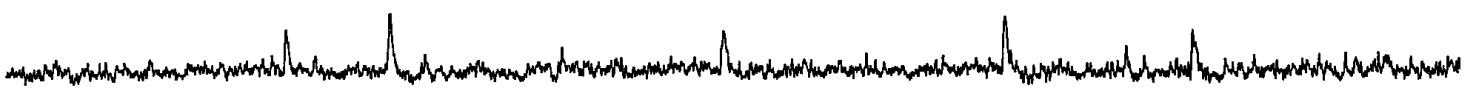

G CGP35348

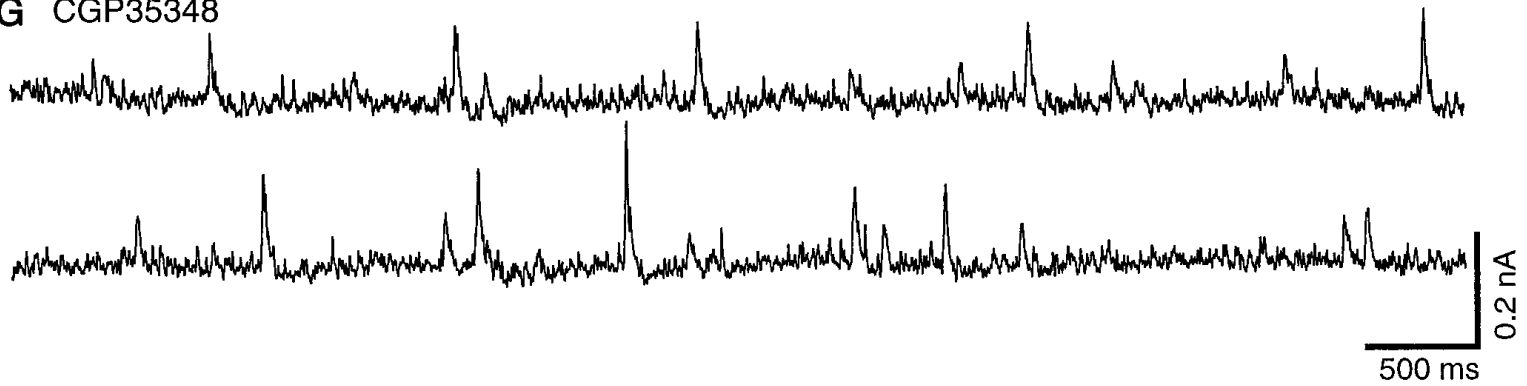

Figure 9. Activation of $\mathrm{GABA}_{\mathrm{B}}$ receptors reduces GABA IPSPs during normal spontaneous and evoked activity. $A$, Examples of IPSPs evoked in a thalamocortical cell after the application of glutamate in the PGN $\left(V_{m}=-74 \mathrm{mV}\right) . B$, Local application of CGP35348 (2 mM in micropipette) results in an enhancement of the amplitude of the evoked IPSPs. Lower traces are averages of the evoked IPSPs before and after application of CGP 35348 for comparison. $C$, IPSCs evoked in a thalamocortical neuron $\left(V_{\mathrm{H}}=-64 \mathrm{mV}\right)$ by the local application of glutamate in the PGN. The evoked IPSCs are followed by IPSCs associated with the generation of spindle waves. $D$, The local application of CGP 35348 results in a marked enhancement of the evoked and spindle wave-associated IPSCs. One example before and after application of CGP 35348 is overlain for comparison. E, Local application of CGP 35348 results in an enhancement in the amplitude of spontaneous IPSCs that occurs between spindle waves. $F$, Examples of spontaneous IPSCs before application of CGP35348 $\left(V_{\mathrm{H}}=-62 \mathrm{mV}\right)$. $G$, Examples of spontaneous IPSCs after the application of CGP 35348. These data were obtained from three different cells $(A, B ; C, D ;$ and $E-G)$, none of which were previously exposed to exogenous GABA, baclofen, or CGP 35348 . 


\section{Cellular mechanisms for activation of $\mathrm{GABA}_{B}$ receptors}

Our results, along with previous investigations in the hippocampus, suggest that the activation of $\mathrm{GABA}_{\mathrm{B}}$ receptors to a sufficient degree to initiate a detectable IPSP requires the strong discharge of GABAergic neurons (Thompson and Gähwiler, 1992; Isaacson et al., 1993), although it has also been suggested that the GABAergic neurons that activate $\mathrm{GABA}_{\mathrm{A}}$ and $\mathrm{GABA}_{\mathrm{B}}$ receptor-mediated IPSPs represent distinct populations of interneurons (Lacaille and Schwartzkroin, 1988; Sugita et al., 1992). Previous dual intracellular recordings in the hippocampus, or examination of spontaneous unitary IPSPs, have demonstrated inhibitory potentials that seem to be mediated entirely by GABA $_{\mathrm{A}}$ receptors (Miles, 1990; Otis and Mody, 1992; Buhl et al., 1994; Debanne et al., 1995). However, strong or repetitive stimulation, the reduction of GABA uptake, or the enhancement of transmitter release results in the additional activation of $\mathrm{GABA}_{\mathrm{B}}$ receptors (Otis and Mody, 1992; Isaacson et al., 1993). Similarly, we have found with dual intracellular recordings that activation of bursts or trains of action potentials in single PGN neurons preferentially activates $\mathrm{GABA}_{\mathrm{A}}$ receptor-mediated IPSPs in thalamocortical cells, although the application of the $\mathrm{GABA}_{\mathrm{A}}$ receptor antagonist bicuculline can leave a small $(<2 \mathrm{mV})$ residual IPSP that is mediated by $\mathrm{GABA}_{\mathrm{B}}$ receptors (Kim et al., 1997). Together with the present results, these findings suggest that the activation of a $\mathrm{GABA}_{\mathrm{B}}$ IPSP that is large enough to generate a rebound low threshold $\mathrm{Ca}^{2+}$ spike requires the simultaneous release of GABA from a number of presynaptic GABAergic neurons.

There are numerous reasons why the release of GABA from a single presynaptic terminal may generate a smaller $\mathrm{GABA}_{\mathrm{B}}$ than $\mathrm{GABA}_{\mathrm{A}}$ receptor-mediated IPSP or IPSC, including differences in driving force, density, sensitivity, and distribution of receptors or channels, and properties of second messenger systems. Recent investigation of $\mathrm{GABA}_{\mathrm{B}}$ receptors on CA3 pyramidal cells have revealed that $\mathrm{GABA}_{\mathrm{B}}$ receptor-mediated increases in $\mathrm{K}^{+}$conductance actually exhibit a lower $\mathrm{EC}_{50}(1.6 \mu \mathrm{M})$ than do $\mathrm{GABA}_{\mathrm{A}}$ receptor-mediated increases in $\mathrm{Cl}^{-}$conductance $(25 \mu \mathrm{M})$ (Sodickson and Bean, 1996). Here we demonstrated that increasing the duration of application of a constant concentration of GABA $(0.5 \mathrm{~mm})$ activated $\mathrm{GABA}_{\mathrm{A}}$ and $\mathrm{GABA}_{\mathrm{B}}$ receptors with approximately the same threshold in most cells, and in the remaining neurons $\mathrm{GABA}_{\mathrm{A}}$ responses exhibited a slightly lower threshold than $\mathrm{GABA}_{\mathrm{B}}$ responses (Fig. 5). One possible explanation for this apparent discrepancy is that in our current-clamp recordings $\mathrm{GABA}_{\mathrm{A}}$ receptor-mediated responses are more easily detected owing to their higher maximal amplitude. Another is that detect-

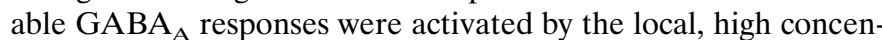
tration of GABA near the tip of the application micropipette, whereas detectable $\mathrm{GABA}_{\mathrm{B}}$ responses required slightly larger applications over a larger portion of the recorded neuron. Given that $\mathrm{GABA}_{\mathrm{B}}$ receptor-mediated responses have a substantially lower $\mathrm{EC}_{50}$ than $\mathrm{GABA}_{\mathrm{A}}$ receptor-mediated responses, the requirement for more intense activation of presynaptic GABAergic neurons to activate $\mathrm{GABA}_{\mathrm{B}}$ receptor-mediated IPSPs argues strongly for an extrasynaptic location of these receptors (Sodickson and Bean, 1996), as has been suggested previously (Thompson and Gähwiler, 1992; Isaacson et al., 1993; Mody et al., 1994).

Activation of $\mathrm{GABA}_{\mathrm{B}}$ receptor-mediated IPSPs in thalamocortical neurons is associated with a delay of $\sim 20-50 \mathrm{msec}$ (Kim et al., 1997), which is similar to previous findings (Alger, 1984; Crunelli et al., 1988; Soltesz et al., 1989; Otis et al., 1993). This delay is likely to result from the multistep process of $\mathrm{GABA}_{\mathrm{B}}$ receptor to channel coupling, including GDP/GTP exchange, diffusion of activated subunits of the G-protein, and channel activation by these subunits (Destexhe and Sejnowski, 1995; Sodickson and Bean, 1996). Similar delays in the G-protein-mediated activation of $\mathrm{K}^{+}$currents have been observed, such as the response of submucosus plexus neurons to noradrenaline $\mathrm{Su}$ prenant and North, 1988) and the response of myocytes to acetylcholine (Inomata et al., 1989).

In addition to postsynaptic $\mathrm{GABA}_{\mathrm{B}}$ receptors, our results together with previous studies (Emri et al., 1996; Ulrich and $\mathrm{Hu}-$ guenard, 1996; Le Feuvre et al., 1997) demonstrate that $\mathrm{GABA}_{\mathrm{B}}$ receptors are also present on the presynaptic terminals of both GABAergic neurons as well as excitatory afferents in the thalamus and that the activation of these receptors results in the reduction of neurotransmitter release. In addition, these studies also demonstrate that there is sufficient extracellular GABA to result in a tonic decrease in amplitude in PGN-evoked IPSPs and optic tract-evoked EPSPs, as well as the frequency of occurrence of spontaneous IPSPs (Emri et al., 1996; Le Feuvre et al., 1997) (Fig. 9). These results suggest that the activation of presynaptic $\mathrm{GABA}_{\mathrm{B}}$ receptors may play an important role in the regulation of intrathalamic activity. Indeed, Ulrich and Huguenard (1996) have demonstrated that repetitive activation of thalamic reticular inputs to thalamocortical neurons results in paired pulse inhibition of IPSP amplitude through the activation of $\mathrm{GABA}_{\mathrm{B}}$ receptors. One attractive hypothesis is that the activation of presynaptic $\mathrm{GABA}_{\mathrm{B}}$ receptors may be responsible, at least in part, for the "waning" or cessation of intrathalamic oscillations such as spindle waves. However, we have demonstrated previously that the block of $\mathrm{GABA}_{\mathrm{B}}$ receptors is not associated with a block of the waning of spindle waves (Bal et al., 1995a,b) and that the block of $\mathrm{I}_{\mathrm{h}}$ with the local application of $\mathrm{Cs}^{+}$results in the occurrence of continuous and repetitive IPSPs, despite the lack of block of GABA receptors (Bal and McCormick, 1996). Therefore, although a clear functional role for postsynaptic $\mathrm{GABA}_{\mathrm{B}}$ receptors in the generation of pathological forms of activity can be hypothesized, a role for the activation of presynaptic $\mathrm{GABA}_{\mathrm{B}}$ receptors, other than to continuously regulate GABA release, is not yet clear.

\section{REFERENCES}

Aghajanian GK, Rasmussen K (1989) Intracellular studies in the facial nucleus illustrating a simple new method for obtaining viable motoneurons in adult rat brain slices. Synapse 3:331-338.

Alger BE (1984) Characteristics of a slow hyperpolarizing synaptic potential in rat hippocampal pyramidal cells in vitro. J Neurophysiol 52:892-910.

Andersen P, Sears TA (1964) The role of inhibition in the phasing of spontaneous thalamo-cortical discharge. J Physiol (Lond) 173:459-480.

Avoli M, Gloor P, Kostopoulos G, Gotman J (1983) An analysis of penicillin-induced generalized spike and wave discharge using simultaneous recordings of cortical and thalamic single neurons. J Neurophysiol 50:819-837.

Avoli M, Gloor P, Kostopoulos G, Naquet R (1990) Generalized epilepsy. Neurobiological approaches. Boston: Birkhauser.

Bal T, McCormick DA (1996) What stops synchronized thalamocortical oscillations? Neuron 17:297-308.

Bal T, von Krosigk M, McCormick DA (1995a) Synaptic and membrane mechanisms underlying synchronized oscillations in the ferret LGNd in vitro. J Physiol (Lond) 483:641-663.

Bal T, von Krosigk M, McCormick DA (1995b) Role of the ferret perigeniculate nucleus in the generation of synchronized oscillations in vitro. J Physiol (Lond) 483:665-685.

Bowery N (1989) GABA $_{\mathrm{B}}$ receptors and their significance in mammalian pharmacology. Trends Pharmacol Sci 10:401-407.

Buhl EH, Halasy K, Somogyi P (1994) Diverse sources of hippocampal 
unitary inhibitory postsynaptic potentials and the number of synaptic release sites. Nature 368:823-828.

Buzsáki G, Smith A, Berger S, Fisher LJ, Gage FH (1990) Petit mal epilepsy and Parkinsonian tremor: hypothesis of a common pacemaker. Neuroscience 36:1-14.

Crunelli V, Leresche N (1991) A role for $\mathrm{GABA}_{\mathrm{B}}$ receptors in excitation and inhibition of thalamocortical cells. Trends Neurosci 14:16-21.

Crunelli V, Haby M, Jassik-Gerschenfeld D, Leresche N, Pirchio M (1988) $\mathrm{Cl}^{-}$and $\mathrm{K}^{+}$-dependent inhibitory postsynaptic potentials evoked by interneurons of the rat lateral geniculate nucleus. J Physiol (Lond) 399:153-176.

Debanne D, Guerineau NC, Gahwiler BH, Thompson SM (1995) Physiology and pharmacology of unitary synaptic connections between pairs of cells in areas CA3 and CA1 of rat hippocampal slice cultures. J Neurophysiol 73:1282-1294.

Deschênes M, Paradis M, Roy JP, Steriade M (1984) Electrophysiology of neurons of lateral thalamic nuclei in cat: resting properties and burst discharges. J Neurophysiol 51:1196-1219.

Destexhe A, Sejnowski TJ (1995) G-protein activation kinetics and spillover of gamma-aminobutyric acid may account for differences between inhibitory responses in the hippocampus and thalamus. Proc Natl Acad Sci USA 92:9515-9519.

Emri Z, Turner JP, Crunelli V (1996) Tonic activation of presynaptic $\mathrm{GABA}_{\mathrm{B}}$ receptors on thalamic sensory afferents. Neuroscience 72:689-698.

Gloor P, Avoli M, Kostopoulos G (1990) Thalamocortical relationships in generalized epilepsy with bilaterally synchronous spike-and-wave discharge. In: Generalized epilepsy. Neurobiological approaches (Avoli M, Gloor P, Kostopoulos G, Naquet R, eds), pp 190-212. Boston: Birkhauser.

Hosford DA, Clark S, Cao Z, Wilson WA, Lin F-H, Morisett RA, Huin A (1992) The role of GABA-B receptor activation in absence seizures of lethargic $(\mathrm{lh} / \mathrm{lh})$ mice. Science 257:398-401.

Huguenard JR, Prince DA (1994) Intrathalamic rhythmicity studied in vitro: nominal $\mathrm{T}$ current modulation causes robust anti-oscillatory effects. J Neurosci 14:5845-5502.

Inomata N, Ishihara T, Akaike N (1989) Activation kinetics of the acetylcholine-gated potassium current in isolated atrial cells. Am J Physiol 257:C646-C650.

Isaacson JS, Solis JM, Nicoll RA (1993) Local and diffuse synaptic actions of GABA in the hippocampus. Neuron 10:165-175.

Jones EG (1985) The thalamus. New York: Plenum.

Kim U, Bal T, McCormick DA (1995) Spindle waves are propagating synchronized oscillations in the ferret LGNd in vitro. J Neurophysiol 74:1301-1323.

Kim U, Sanchez-Vives MV, McCormick DA (1997) Functional dynamics of GABAergic inhibition in the thalamus. Science 278:130-134.

Lacaille JC, Schwartzkroin PA (1988) Stratum lacunosum-moleculare interneurons of hippocampal CA1 region. II. Intrasomatic and intradendritic recordings of local circuit synaptic interactions. J Neurosci 5:1411-1424.

Le Feuvre Y, Fricker D, Leresche N (1997) GABA $_{A}$ receptor-mediated IPSCs in rat thalamic sensory nuclei: patterns of discharge and tonic

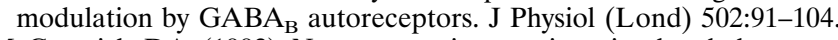

McCormick DA (1992) Neurotransmitter actions in the thalamus and cerebral cortex and their role in neuromodulation of thalamocortical activity. Prog Neurobiol 39:337-388.

McCormick DA, Pape H-C (1990) Properties of a hyperpolarizationactivated cation current and its role in rhythmic oscillation in thalamic relay neurons. J Physiol (Lond). 431:291-318.

Miles R (1990) Variation in strength of inhibitory synapses in the CA3 region of guinea-pig hippocampus in vitro. $\mathrm{J}$ Physiol (Lond) 431:659-676.

Mody I, De Koninck Y, Otis TS, Soltesz I (1994) Bridging the cleft at GABA synapses in the brain. Trends Neurosci 17:517-525.
Otis TS, Mody I (1992) Differential activation of $\mathrm{GABA}_{\mathrm{A}}$ and $\mathrm{GABA}_{\mathrm{B}}$ receptors by spontaneously released transmitter. $\mathrm{J}$ Neurophysiol 67:227-235.

Otis TS, De Koninck Y, Mody I (1993) Characterization of synaptically elicited $\mathrm{GABA}_{\mathrm{B}}$ responses using patch-clamp recordings in rat hippocampal slices. J Physiol (Lond) 463:391-407.

Sanchez-Vives MV, Bal T, McCormick DA (1995) Properties of GABAergic inhibition in the ferret LGNd contributing to the generation of synchronized oscillations. Soc Neurosci Abstr 21:11.

Sanchez-Vives MV, Bal T, Kim U, von Krosigk M, McCormick DA (1996) Are the interlaminar zones of the ferret dorsal lateral geniculate nucleus actually part of the perigeniculate nucleus? J Neurosci 16:5923-5941.

Sanchez-Vives MV, Bal T, McCormick DA (1997) Inhibitory interactions between perigeniculate GABAergic neurons. $J$ Neurosci 17:8894-8908.

Shosaku A, Kayama Y, Sumitomo I, Sugitani M, Iwama K (1989) Analysis of recurrent inhibitory circuit in rat thalamus: neurophysiology of the thalamic reticular nucleus. Prog Neurobiol 32:77-102.

Snead OC (1992) Evidence for GABA-B mediated mechanisms in experimental generalized absence seizures. Eur J Pharmacol 213:343-349.

Sodickson DL, Bean BP (1996) GABA $_{B}$ receptor-activated inwardly rectifying potassium current in dissociated hippocampal CA3 neurons. J Neurosci 16:6374-6385.

Soltesz I, Crunelli V (1992) A role for low-frequency, rhythmic synaptic potentials in the synchronization of cat thalamocortical cells. J Physiol (Lond) 457:257-276.

Soltesz,I, Lightowler S, Leresche N, Crunelli V (1989) On the properties and origin of the $\mathrm{GABA}_{\mathrm{B}}$ inhibitory postsynaptic potential recorded in morphologically identified projection cells of the cat dorsal lateral geniculate nucleus. Neuroscience 33:23-33.

Staley KJ, Soldo, BL, Proctor WR (1995) Ionic mechanisms of neuronal excitation by inhibitory GABA A receptors. Science 269:977-981.

Steriade M, Deschênes M (1984) The thalamus as a neuronal oscillator. Brain Res Rev 8:1-63.

Steriade M, Deschênes M, Domich L, Mulle C (1985) Abolition of spindle oscillations in thalamic neurons disconnected from nucleus reticularis thalami. J Neurophysiol 54:1473-1497.

Steriade M, McCormick DA, Sejnowski TJ (1993) Thalamocortical oscillations in the sleeping and aroused brain. Science 262:679-685.

Sugita S, Johnson SW, North RA (1992) Synaptic inputs to GABA And $_{\text {and }}$ and $\mathrm{GABA}_{\mathrm{B}}$ receptors originate from discrete afferent neurons. Neurosci Lett 134:207-211.

Suprenant A, North RA (1988) Mechanism of synaptic inhibition by noradrenaline acting at $\alpha_{2}$-adrenoceptors. Proc R Soc Lond [Biol] 234:85-114.

Thompson SM, Gähwiler BH (1992) Effects of the GABA uptake inhibitor tiagabine on inhibitory synaptic potentials in rat hippocampal slice cultures. J Neurophysiol 67:1698-1701.

Thomson A (1988) Inhibitory postsynaptic potentials evoked in thalamic neurons by stimulation of the reticularis nucleus evoke slow spikes in isolated rat brain slices Neuroscience 25:491-502.

Ulrich D, Huguenard JR (1995) Purinergic inhibition of GABA and glutamate release in the thalamus: implications for thalamic network activity. Neuron 15:909-918.

Ulrich D, Huguenard JR (1996) GABA $_{\mathrm{B}}$ receptor-mediated responses in GABAergic projection neurones of rat nucleus reticularis thalami in vitro. J Physiol (Lond) 493:845-854.

von Krosigk M, Bal T, McCormick DA (1993) Cellular mechanisms of a synchronized oscillation in the thalamus. Science 261:361-364.

Vuong TM, Chabre M, Stryer L (1984) Millisecond activation of transducin in the cyclic nucleotide cascade of vision. Nature 311:659-661.

Warren RA, Agmon A, Jones EG (1994) Oscillatory synaptic interactions between ventroposterior and reticular neurons in mouse thalamus in vitro. J Neurophysiol 72:1993-2003. 